\title{
Customer reactions to a webshop's service quality
}

\author{
Franz Hackl ${ }^{1}$ iD $\cdot$ Rudolf Winter-Ebmer ${ }^{1,2,3,4}$
}

Published online: 17 July 2019

(c) The Author(s) 2019

\begin{abstract}
E-commerce has become an integral part of the world's economy. In this study we investigate the impact of service quality in e-tailing on site visits and consumer demand. Such an analysis is important given the almost Bertrand-like competitive structure. Our analysis is based on a large representative data set obtained from a price comparison site covering essentially the complete Austrian e-tailing market. Customer evaluations for a broad range of 15 different service characteristics are condensed using factor analysis. Negative binomial regression analysis is used to measure the impact of service quality dimensions on referral requests to online shops for different product categories. Our results show that the most important service quality aspects are those related to the ordering process and the firm's website performance.
\end{abstract}

Keywords E-commerce $\cdot$ Price comparison $\cdot$ Horizontal service differentiation

JEL Classification M31 $\cdot \mathrm{L} 81 \cdot \mathrm{L} 25$

\section{Introduction}

E-commerce has become an integral part of the world's economy. The share of goods and services traded via e-commerce amounted to $2.59 \%$ of the GDP of Europe in 2015 (North America: 2.55\%, Asia-Pacific: 3.33\%). The estimated share of online goods in the total retail of all goods was $8.0 \%$ for Europe (North America

Franz Hackl

franz.hackl@jku.at

1 Department of Economics, JKU Linz, Linz, Austria

2 IHS, Vienna, Austria

3 IZA, Bonn, Germany

4 CEPR, London, UK 
4.2\% and Asia Pacific: 5.4\%). ${ }^{1}$ The proliferation of price comparison sites or shopbots have resulted in very fierce price competition in e-commerce, therefore, a firm's service characteristics have gained substantial importance.

Retailers' service characteristics have became a crucial determinant of firm competitiveness for two reasons: (i) As online shops trade essentially homogeneous factory-made products, the only way to differentiate them is the strategic choice of different service characteristics. While some retailers might set higher prices for outstanding service and, therefore, expect higher profits, other shops might hope for higher demand resulting from Spartan service and low product prices. (ii) Generally, a firm's service characteristics make a major contribution to resolving problems of asymmetric information in e-commerce. Should consumers pay in advance if they cannot inspect the product that they get delivered (if at all), or should retailers send a commission in advance not knowing whether they will be paid? Information about the service quality of a shop can be very important in reducing uncertainty in the e-commerce business. Information about the firms' service characteristics has the potential to build trust and reduce uncertainty about payment and delivery. Post-shopping services, including grievance procedures or redemption policies are other important pieces of information that potential customers would like to know. Having access to these service characteristics assigns a larger role to non-price marketing, which can usually consist of pre-and post-sale services.

In the e-commerce business, strategic decisions on different customer services cost money. Hence, e-tailers are interested in the impact of different service characteristics on customer attention on their shops and sales volumes. Based on the behavior of visitors from a large Austrian price search engine (www.geizhals.at ${ }^{2}$ ) covering most of the national (Austrian) e-tailing market, we provide evidence on the importance of different service characteristics in the e-commerce business. The firms' service characteristics are predefined by www.geizhals.at and are based on costumer evaluation forms on the website of the price search engine. These data allow us to examine a broad range of 15 different service characteristics of individual e-businesses, such as accessibility, assortment, information and advice, convenience of the website, reliability of order fulfillment, and the delivery modalities provided by the evaluations of past shoppers. Customers judge the quality of the service characteristics following a school grade system. Hence, our analysis is based on the actual perceived service quality by customers. Using negative binomial panel estimations, we calculate the impact of the quality of different service aspects on customer attention for online shops and a proxy for estimated sales volumes. Sales quantities are approximated with the so-called Last-Click-Through (LCT) concepta procedure that is used to estimate the shops' conversion rate of visits into actual product sales.

\footnotetext{
${ }^{1}$ All figures are from: www.ecommerce-europe.eu. Values for North America and Asia-Pacific are from 2014.

2 The German word "Geizhals" means "skinflint" or "penny pincher".
} 
Our measurement of attention and the proxy for actual sales is based on the amount of referral requests from the www.geizhals.at-website to the webshophomepage. A referral request is a click on a firm offer listed in the price search engine, resulting in a redirect to the e-tailer's webpage. ${ }^{3}$ Given the dominance of www.geizhals.at as the information broker, these clicks are an extremely important indicator of the attractiveness of an online shop; www.geizhals.at is the only price search engine in Austria, and is therefore, often visited. ${ }^{4}$ Hence, the best-price offers listed in the price search engine also exert pressure on the other bidders and reduce their profit margins. On the other hand, online shops depend on www.geizhals.at, as the price search engine brings them many customers. The following quote from an Austrian e-commerce manager highlights the dominance of www.geizhals.at: "the first day we are no longer dependent on www.geizhals.at will be the best day of my life" (Source: personal conversation). Simultaneously, this quote reveals that our dependent variable (clicks) is an important indicator of success in the e-commerce business in Austria. ${ }^{5}$

In our study, we systematically investigate the impact of service quality components in e-tailing on site visits, and therefore, indirectly on consumer demand. Previous research on e-tailers either has (1) identified dimensions of service quality (Zeithaml et al. 2002) or (2) studied how these dimensions/attributes influence perceptions such as satisfaction, purchase intentions, or trust (Bart et al. 2005). Our study bridges a gap by considering how these dimensions influence actual consumer purchases in online markets. Our study complements studies on price differences, by showing how reputation and different components of customer satisfaction have a direct influence on clicking behavior. These results allow for conclusions about the relative importance of different service characteristics in e-commerce.

Furthermore, we will analyze product-specific differences on the importance of different components of customer service. Obviously, consumers of software products will have different expectations from e-tailer service quality (e.g. fast download) than those that buy a refrigerator (e.g. robust packaging). Similarly, we would expect different impacts of service quality for buyers of high- or low-priced products. As many online shops specialize in certain types and categories of products, it is important to know how the different aspects of customer service will impact their business. From a marketing perspective, these results enable the design of an optimal marketing mix which aligns the retailer's individual cost structure for services with its impact on the market in the form of customer attention and demand (click data). Our results are corroborated when we observe informed consumers who gather specific information about shop quality.

\footnotetext{
${ }^{3}$ By observing referral requests to the e-tailer's websites, we can determine the number of vendors in the shopper's consideration set (Hauser and Wernerfelt 1990).

${ }^{4}$ With 40 million page impressions and 2.6 million unique clients per month, geizhals.at is one of the largest price comparison platforms in German-speaking countries (Source: OEWA annual average 2016, acquired from the geizhals.at homepage).

${ }^{5}$ According to the manager, half their sales is mediated by www.geizhals.at (Source: personal conversation).
} 
The paper is organized as follows: Sect. 2 discusses the literature on this topic. Section 3 presents the theoretical framework for service differentiation. The data are discussed in Sect. 4, Sect. 5 presents our empirical results, Sect. 6 contains a summary of the managerial implications, and Sect. 7 discusses conclusions.

\section{Literature}

Despite extensive literature on the marketing mix in brick-and-mortar stores-for a survey see Constantinides (2006) — contributions on e-tailing are scarce. For offline retailing, Homburg et al. (2002) present a comprehensive study on the dimensions and determinants of service orientation as part of a retailer's business strategy, as well as its impact on the profitability of retailers in the clothing and furniture sectors. $^{6}$

For the online sector, Zeithaml et al. (2002) define service as comprehensive preand post-website aspects, with particular emphasis on information availability, ease of use, security/privacy, and fulfillment/reliability as defining aspects. Kalyanam and McIntyre (2002), Bauer et al. (2006), Parasuraman et al. (2005) and Wolfinbarger and Gilly (2003) also categorize service quality in an e-marketing mix. Bauer et al. (2006) as well as Wolfinbarger and Gilly (2003) use a structured survey to assess the impact of service quality on satisfaction with the e-tailer and repurchase intentions. ${ }^{7}$ Our study alludes to this literature by going beyond survey data to examine the actual buying intentions of customers.

Trust in and the reputation of websites are particularly important service categories, which particularly apply to shopping with the aid of a price comparison site. Bart et al. (2005) analyze a large survey of over 6000 respondents and find that the determinants of online trust differ across site categories and consumers. While privacy and order fulfillment are found to be most important for travel sites, navigation, advice, and once again, order fulfillment, are most important for e-tailing. In terms of satisfaction with payment conditions, Schlosser et al. (2006) use an experimental approach to investigate the impact of website design on trust and purchase intentions, and find that a higher investment in web design is important for establishing trust, for both unknown and well-known firms. Similarly, Resnick et al. (2006) use experimental evidence for reputation effects on the e-Bay platform. ${ }^{8}$ See also Nisar and Prabhakar (2017) on the impact of e-satisfaction on consumer spending and Oliveira et al. (2017) on interactions between various forms of trust and the intention to buy. Our study adds to the literature by systematically investigating different service characteristics and products.

\footnotetext{
${ }^{6}$ See Worm et al. (2017) on the impact of service customer solutions on a firm's success.

7 See also Blake et al. (2005) and Oh et al. (2008) for survey studies on website features such as site design and innovativeness and their impact on consumer patronage by experienced and initial shoppers.

${ }^{8}$ Cabral and Hortaçsu (2010) show that consumers react stronger to negative feedback than positive fellow customer evaluations.
} 
Similar to our study, Thompson and Haynes (2017) examine field data from a price comparison site. Using data on digital cameras, they show that seller reputation - as measured by customer evaluations - has a positive, but relatively small effect on prices in such online markets. Fan et al. (2016) study reputation effects of old and new firms on the Chinese platform taobao.com and find that reputation has no effect on new firms. ${ }^{9}$ Our study explicitly examines a price comparison site to study different aspects of reputation and buyer's service characteristics.

\section{Theoretical background}

In e-commerce markets, consumers have different preferences for service characteristics offered by online stores. For example, some consumers are interested in a lot of information about the goods on the shop's website; others want certain payment options or especially short delivery times, and so on. Since products can only be bought via retailers, a customer's decision to choose a certain retailer is essentially a decision to choose the retailer's services. It is reasonable to assume that consumers try to make the best decisions for themselves (= utility maximization).

Online shops are assumed to meet these preferences by an appropriate strategic choice of these service characteristics. Retailers maximize the firms' profits within a framework of vertical and horizontal product/service differentiation. ${ }^{10}$ In a world without cost, we would expect all webshops to offer the best service quality on all service dimensions the customers might appreciate. However, if the cost of service provision matters, firms will specialize in certain types of services (= horizontal dimension) for which they have to choose the optimal quality levels (= vertical dimension) to maximize profits. Some examples of the horizontal dimension are as follows: simplicity of website navigation, validity of online information, delivery time, packing and content of consignment, and so on. For each service category, the shop has to decide the level of service quality-this decision refers to the vertical dimension. Broadening the types of services (horizontal differentiation) and improved quality standards for these services (vertical differentiation) will increase retailers' costs, and thereby, the price. In equilibrium, we would expect that different service characteristics are one reason for the spread of bid prices from different online merchants-a phenomenon that is also called price dispersion.

Given the cost structure of services, the utility- and profit maximizing behavior of consumers and online shops will result in a direct hedonic price function $p_{j}=p_{j}\left(q_{j}, s_{j}^{h, v}\right)$, where the price for the homogeneous good of retailer $j$ is determined

\footnotetext{
${ }^{9}$ Cai et al. (2014), Elfenbein et al. (2012), and Klein et al. (2016) study reputation effects in eBay, whereas Einav et al. (2016) provide a review of peer-to-peer markets.

${ }^{10}$ Mussa and Rosen (1978) or Gabszewicz and Thisse (1979), and subsequent studies on the oligopoly case might represent a starting point for an underlying theoretical model. Lancaster (1966) and Rosen (1974) stress the multidimensionality of consumer decisions.
} 
by the quantity $q$ and the characteristics of the services offered $s^{h, v}$ by retailer $j ; h$ refers to the horizontal dimension of the product/service differentiation, $v$ stands for the vertical dimension. Assuming identical wholesale prices for all retailers, the product/service differentiation approach claims a stable relationship between the traded quantities per retailer, the retailer's prices, and the retailer's service characteristics. The direct hedonic price function can also be transformed into an indirect hedonic price function with quantity as the dependent variable: $q_{j}=p_{j}\left(p_{j}, s_{j}^{h, v}\right)$. This indirect hedonic price function represents the theoretic framework for our econometric analysis further on.

Note that different service characteristics are a major reason for the existence of price dispersion-the spread of prices for the same good at a given point in time. Obviously, different service characteristics are not the only cause of price dispersion in real existing markets. We discuss other reasons that have the potential to influence our indirect hedonic price function:

(i) Carlson and McAfee (1983) and Stigler (1991) discuss customers' search costs for the various offering firms. They show that a positive price dispersion can be an equilibrium outcome where the marginal cost of additional search is equal to the marginal gain of the search. ${ }^{11}$ Although the internet should significantly reduce search cost, these costs will not disappear completely. Owing to the abundance of obfuscation strategies (e.g. low prices and high shipping cost, low prices for not available products, and so on, see Ellison and Ellison (2009)) the true nature of the price structure is often difficult to decipher. (ii) Fishman (1992) argues that menu cost might result in staggered prices, and therefore, price dispersion; however, the counter-argument is that, especially in online markets, menu costs are particularly low. Even if the physical cost of changing price tags is negligible, the managerial decision cost of the strategic answers to the price policy of competitors cannot be ignored. (iii) The profit-maximizing price discrimination of firms could also be responsible for the price dispersion of a homogeneous good. In Clemons et al. (2002), different degrees of information result in price discrimination by consumers, whose nature is established as price dispersion.

We will cover these alternative explanations for price dispersion with product fixed effects, which should at least partly control for idiosyncratic product differences with regard to these alternative explanations.

\section{Data and estimation strategy}

Data:Ourempiricalanalysisisbasedonthedatabase availableathttp://www.geizhals.at. This website is a "price search engine", which collects the price offers via standardized protocols from a predefined group of sellers and presents them electronically via its web platform. www.geizhals.at has contracts with several hundred retailers

\footnotetext{
11 Burdett and Judd (1983), Burdett and Coles (1997), and Salop and Stiglitz (1982) provide additional arguments where search cost hinders consumers in equilibrium to find the lowest price.
} 
which can list their price offerings for their products on www.geizhals.at. Customers can evaluate the service provided by the retailers online. ${ }^{12}$

We use data from an arbitrary week in $2011^{13}$ to reduce the computational load. Since the online shop can change the prices several times a day, we calculated weighted price offers per product and seller over the week observed (using the length of the price spell as weights). Hence, the observational unit in our data is the cross-section of offers from online shop $j$ for the goods $i$. The data used in this analysis include price offers for 66,000 products from a total of 676 sellers, along with 20,538 customer quality evaluations of sellers. Furthermore, the data comprise detailed information on 788,463 customer clicks to retail shops together with the respective views and filter options of the customers.

The sellers' price offers tell us the exact name of the product and the producer, and the mapping of products into a hierarchical classification system (categories, subcategories, and subsubcategories). The classification system is maintained by www.geizhals.at, which also classifies newly emerging products. Therefore, it is identical for all sellers. The sellers' price offers also include information on availability and shipping charges. The customers' clicks reveal the product and retail shop to which the customer wishes to be referred.

In the context of our analysis, we intend to measure the retailers' horizontal and vertical service differentiation $s_{j}^{h, v}$. This will be done using the customer evaluations of the different service characteristics with grades between 1 (= very satisfactory) and 5 (= very unsatisfactory), as well as the "don't know" option for any of the following criteria predefined by www.geizhals.at: navigation on the site, assortment, availability, service, price level, shipping cost, product information, payment modalities, terms of business, website performance, satisfaction with the handling of the offer (order transaction, validity of information, confirmation of order and tracking of shipment, delivery time, packing and content of consignment, service after shipment). The categories are predefined by www.geizhals.at and cover the service aspects of the process of information gathering, decision making, and order handling in a very detailed and comprehensive manner.

Since it is necessary to register on the www.geizhals.at website to post an evaluation, customer evaluations of retailers are considered sufficiently reliable by other consumers. Moreover, www.geizhals.at-in its role as information broker-makes a special effort to check and control these customer comments because its business model relies crucially on the reliability of its data. Customers interested in querying

\footnotetext{
12 Based on data of this price search engine, the following topics have been analyzed. Dulleck et al. (2011) demonstrate that consumers focus on the price only at a very early stage of the buying decision process. The closer the purchase decision, the more important other factors such as service quality and the reputation of a shop become. Hackl et al. (2014a) study the impact of different price endings (e.g. 99-cent prices) on customer behavior. Hackl et al. (2014b) analyze the interaction between market structure and market performance over the products' lifecycles.

13 After 2011, www.geizhals.at stopped using cookies; therefore, for later years, we cannot control whether a consumer actually inspected the individual service characteristics. However, this variable provides important insights in the context of this analysis. Hence, 2011 is the most recent year for which this type of analysis can be done.
} 
retailers' evaluations have three possibilities to do so: (i) The average grade of all the customer evaluations with regard to all the criteria can be seen next to the retailers' price offers. (ii) Customers can also query the average ratings with respect to single service criteria. (iii) Finally, they can inspect each customer evaluation in addition to the open comments, which customers can give together with their evaluations.

Visitors of the price search engine can be identified by their pseudo-anonymous IP-address. ${ }^{14}$ Hence, we can follow the complete search behavior of each individual customer on www.geizhals.at and know for any pseudonym IP-address the sequence of referral requests from www.geizhals.at to the websites of the e-tailers. Referral requests are clicks on the website-link of an online shop in the price search engines listing of firm offers for a specific product. Given the dominance of www.geizhals. at, these clicks are an extremely important indicator of the attractiveness of firms. Although a referral request does not mean that actual purchases will happen, these clicks are a perfect proxy for the customers' attention on a specific shop. We use these clicks from customers to measure the impact of the different service characteristics of the online shops on consumer attention toward shop websites.

However, for the profitability and survival of a retailer, it is not the attention but actual purchases, which matter. Therefore, the conversion rate is an important key figure in the e-commerce business. It is the percentage of the website's visitors that actually make purchases. ${ }^{15}$ As actual conversion rates for our 676 sellers are not available, we use the industry-standard, the number of Last-Click-Throughs (LCT), as an indicator of actual purchases. ${ }^{16}$ As we have the pseudo-anonymous IPaddress of a customer, we can undertake a detailed examination of the search and decision behavior of each individual visitor to the price search engine. If a customer is searching for a product, she might meander around different websites, comparing shop characteristics, but will finally settle for a preferred shop and buy there online. The last click to a shop is usually identified as that with the highest purchase probability. In other words, it is highly unlikely that a person buys at shop A and goes back to www.geizhals.at to look at the same product at another shop later on.

In practice, the determination of the Last-Click-Through is complicated, because buyers can shop for a specific product several times during a particular time interval. When analyzing the click behavior of a customer over time, we have to define a "search period", which is completed with an actual purchasing decision. If the customer searches for several days, then interrupts the search for a month or so, and reappears again, we might have a situation in which a consumer buys more than one specific item at different points in time. Two approaches can be chosen to identify such different search periods. Using hierarchical clustering, which sequentially adds

\footnotetext{
14 Note the following problems with personal identification: devices can be used by more than one individual. IP-addresses might have changed during our observation period (e.g. if Dynamic Host Configuration Protocols DHCP are used). Although personal identification via IP-addresses is not perfect, the quality of our approach should be sufficient for the construction of our variables.

15 Pallant et al. (2017) show that customers coming from a price-comparison site are more likely to purchase a good than customers coming from other sources, for example e-mail marketing.

16 Smith and Brynjolfsson (2001), Bai (2004), or Dulleck et al. (2011) have used the concept of LCT before.
} 
the clicks with respect to their minimal temporal distance, we obtain a dendrogram in which the fixing of a hierarchical level results in a certain amount of search intervals. Choosing a low level results in many search spells, while choosing a high level gives us fewer intervals. Since the definition of the hierarchical level is arbitrary, we decided to find the different search intervals using the Grubbs test for outlier detection. Choosing a significance level of $95 \%$, it is possible to identify those especially long time differences that distinguish different search intervals. ${ }^{17}$ Since, by definition, a search requires the comparison of several alternatives, even a search period of one hour would have outliers. Therefore, we have to introduce some minimal requirements - the sequence of clicks is divided into several search spells if there is a time interval of one week without clicks and the resulting search periods contain at least three clicks. To complicate matters further, customers might not only search for one specific product but also look at substitutes. Hence, instead of the sequence of clicks for a specific good, we used the sequence of clicks within a specific product category to identify the click with the highest probability of conversion into an actual purchase. ${ }^{18}$ We call this click with the highest purchase probability $L C T$. This is an obvious indicator of buying potential, much better than using all clicks. As will be shown in the empirical part, using LCTs improves our estimations of the indirect hedonic price function, as we would expect it for actual purchases. Hence, our LCT variable represents a valid proxy for consumers' actual purchases.

Estimation Strategy: Our dataset is characterized by a high amount of zeros in the regressand: 87 percent of all product offers across the retailers are never selected by customers because of high price or poor evaluation of the retailer. Since the regressand represents a typical non-negative count variable, we use negative binomial panel estimations in which $q_{i j}$ represent our count for the clicks (referral request) on retailer $j$ for product $i$. If overdispersion would not be a problem, $q_{i j}$ would follow a Poisson Distribution with the Poisson parameter $\gamma_{i j}\left(q_{i j} \mid \gamma_{i j} \sim \operatorname{Poisson}\left(\gamma_{i j}\right)\right)$. However, as in all of our models, the likelihood ratio test for overdispersion rejects the Poisson model, our $\gamma_{i j}$ is conditional on the dispersion parameter $\delta_{i}$, and $\gamma_{i j} \mid \delta_{i}$ follows a Gamma distribution $\Gamma$ with parameter values $\lambda_{i j}$ and $\delta_{i}$ :

$$
\gamma_{i j} \mid \delta_{i} \sim \Gamma\left(\lambda_{i j}, \delta_{i}\right)
$$

for which $\log \left(\lambda_{i j}\right)=\alpha X_{i j}+\epsilon_{i j}$. Our vector of independent variables $X_{i j}$ will be discussed below. This results in the fixed-effects negative binomial model, which can be estimated by Maximum-Likelihood estimations ${ }^{19}$ :

$$
\operatorname{Pr}\left(q_{i j} \mid x_{i j}, \delta_{i}\right)=\frac{\Gamma\left(\lambda_{i j}+q_{i j}\right)}{\Gamma\left(\lambda_{i j}\right) \Gamma\left(q_{i j}+1\right)}\left(\frac{1}{1+\delta_{i}}\right)^{\lambda_{i j}}\left(\frac{\delta_{i}}{1+\delta_{i}}\right)^{q_{i j}} .
$$

\footnotetext{
17 For each level in the hierarchical clustering, a certain significance level for the Grubbs test for outlier detection can be found, which results in identical search spells.

18 Variations with these parameters will result in different proxies for actual purchases. We do not report the estimates for these variations in the definition of the $L C T$, as our results are quite consistent and robust with variations in the definition of the $L C T$ variable. See Dulleck et al. (2011) for some tests.

19 See Hausman et al. (1984) or StataCorp (2013) on "xtnbreg" estimations.
} 
We use the following regressors $X_{i j}$ : the variable Rel. Price measures the price of product $i$ of retailer $j$ relative to the average price of product $i$ across all retailers $j$ (hence Rel. Price $_{i j}=\frac{p_{i j}}{\sum_{j=1}^{N} p_{i j} / N}$ ). Horizontal and vertical product/services provision is addressed with the variable $s_{j}^{h, v}$. In the econometric analysis, we use the average of the customer evaluations of all the above-mentioned individual service criteria as well as a measure based on a factor analysis to be discussed below. ${ }^{20}$ Rel. Shipping Cost were calculated from the information available on www.geizhals.at. Germany is equal to 1 if the online shop is located in Germany, and Austria otherwise. Avail is equal to 1 if the product is deliverable at short notice. Pick-up is equal to 1 if the retailer has a pick-up store. Price level denotes the average relative price of all other goods offered by the retailer as an indicator whether the firm is to be considered a bargain store. \#Evaluations counts the number of customers who have evaluated the retailers' service characteristics. \#Inspections is the number of customers who actually observed the detailed evaluations of service characteristics. Descriptives for the variables used can be found in Table 1.

\section{Empirical results}

The main objective of this study is to identify the relevant service characteristics of online shops. However, a regression analysis including all 15 different service characteristics is not appropriate due to the high multicollinearity between the regressors. Table 2 lists the correlation coefficients for the different customer evaluations of the retailers' service characteristics; most characteristics are correlated with a coefficient of correlation larger than 0.7 .

\subsection{Factor analysis}

To transform the number of highly correlated variables into fewer unobserved variables, we use factor analysis, whereby an underlying unobserved variable (called a factor) is constructed as a linear combination of the observed ones. We then exclude the customer evaluations of price because Rel. Price and the Price level capture this attribute in a more direct manner. Since we want to identify the main categories that can be developed from the fourteen different characteristics, we have applied the "Principal Factor Analysis" (see Backhaus et al. 2008 or Basilevsky 1994). As far as the number of underlying factors is concerned, the literature offers various methods, which might lead to different results. ${ }^{21}$ According

\footnotetext{
${ }^{20}$ It might be argued that our results are adversely affected by endogeneity issues, as firms with higher customer demand can afford better service. Our data structure rules out such reverse causation, because we examine demand for one week, which may be triggered by service assessments of past customers; the rating of firms is taken from the beginning of the week. Moreover, the actual rating shown on the website is a cumulative aggregation of customer assessments over the last year.

21 Costello and Osborne (2005) focus on high item loadings, low cross-loadings, and few factors with less than three items.
} 


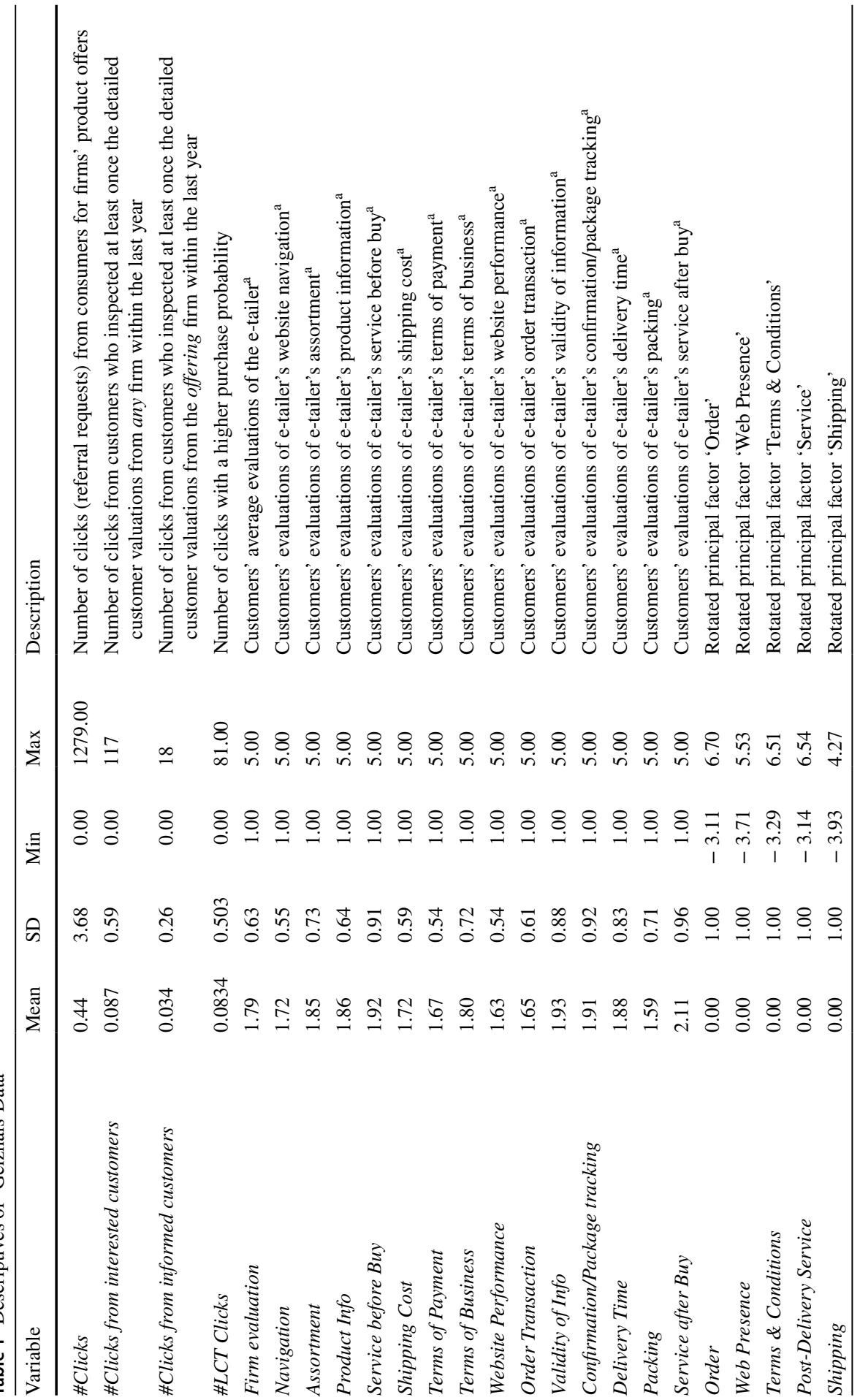




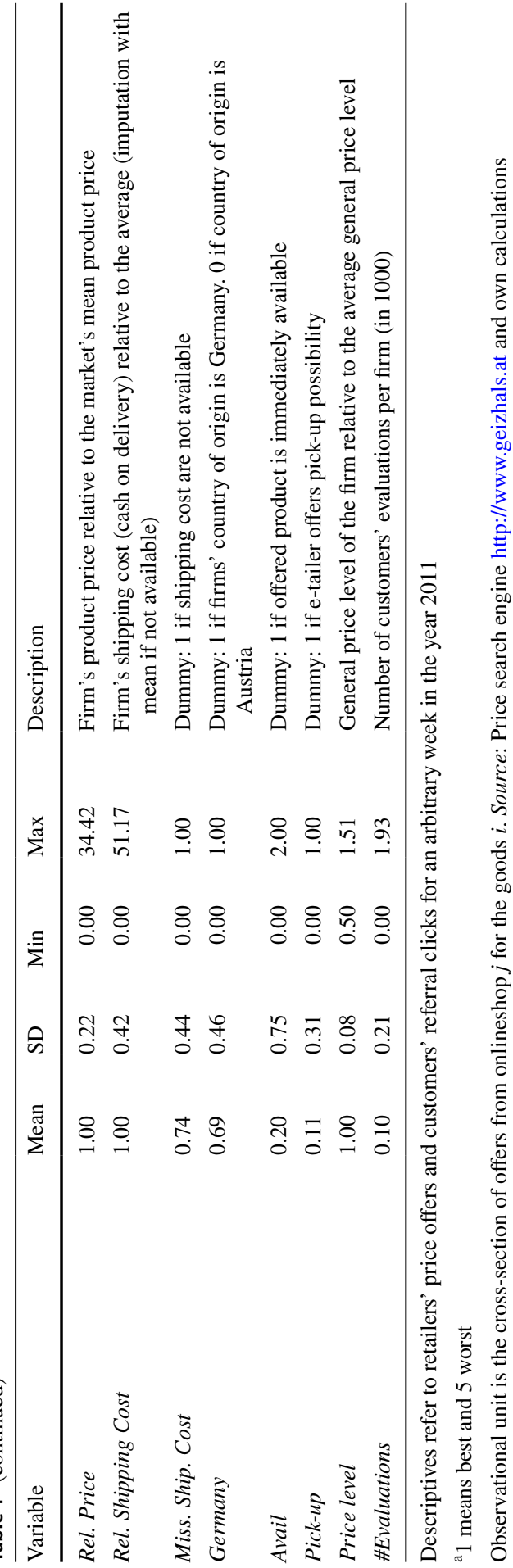




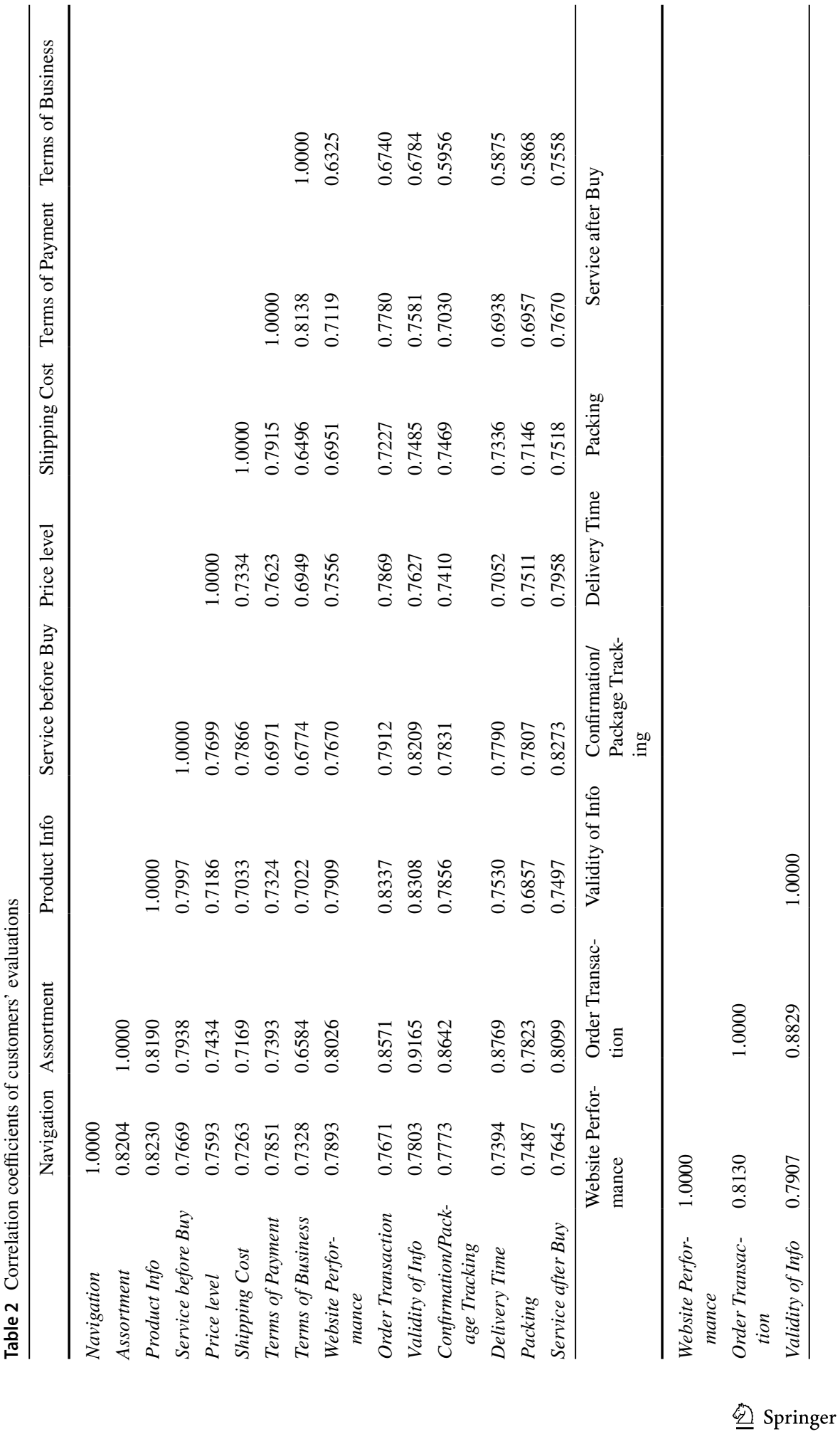




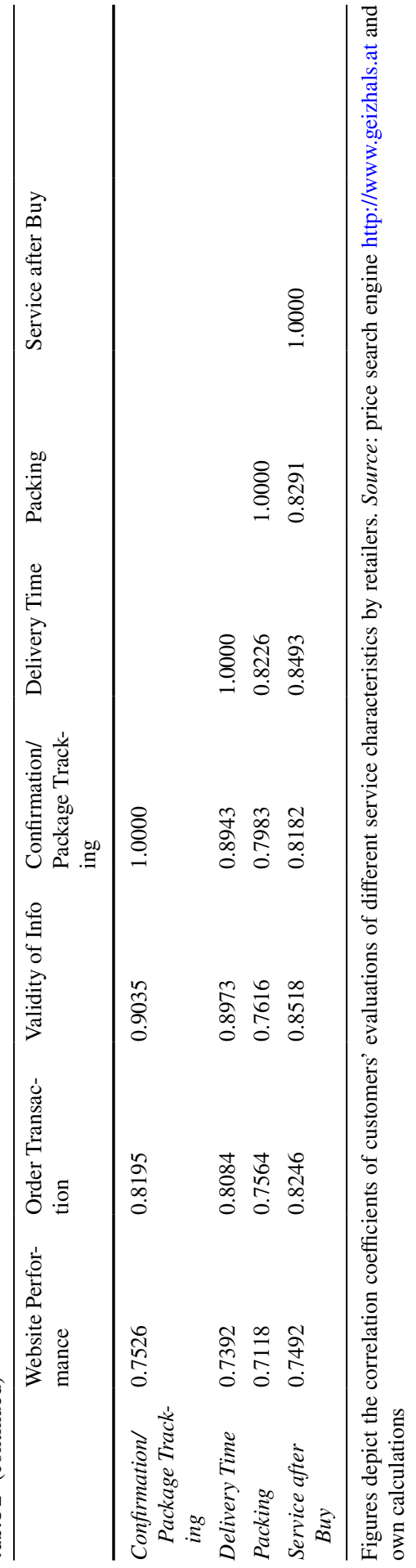


Table 3 Rotated factor loadings

\begin{tabular}{|c|c|c|c|c|c|c|}
\hline & Order & $\begin{array}{l}\text { Terms \& } \\
\text { Condi- } \\
\text { tions }\end{array}$ & Web Performance & $\begin{array}{l}\text { Post- } \\
\text { Delivery } \\
\text { Service }\end{array}$ & Shipping & Uniqueness \\
\hline Navigation & 0.3680 & 0.4659 & 0.5735 & 0.3268 & 0.2615 & 0.1435 \\
\hline Assortment & 0.7091 & 0.3241 & 0.4308 & 0.2685 & 0.2116 & 0.0896 \\
\hline Product Info & 0.4987 & 0.3941 & 0.6354 & 0.1532 & 0.2368 & 0.1126 \\
\hline Service before Buy & 0.3996 & 0.2994 & 0.4710 & 0.4892 & 0.3885 & 0.1385 \\
\hline Shipping Cost & 0.3557 & 0.3255 & 0.2608 & 0.2738 & 0.7767 & 0.0213 \\
\hline Terms of Payment & 0.3713 & 0.6784 & 0.2589 & 0.1593 & 0.4674 & 0.0910 \\
\hline Terms of Business & 0.2373 & 0.8679 & 0.2580 & 0.2174 & 0.1797 & 0.0444 \\
\hline Website Performance & 0.4110 & 0.2786 & 0.6946 & 0.2841 & 0.2585 & 0.1234 \\
\hline Order Transaction & 0.6375 & 0.3820 & 0.4531 & 0.2156 & 0.2554 & 0.1305 \\
\hline Validity of Info & 0.7617 & 0.3463 & 0.3537 & 0.2292 & 0.2698 & 0.0494 \\
\hline Confirm./Package track. & 0.7471 & 0.2269 & 0.3109 & 0.3221 & 0.3140 & 0.0914 \\
\hline Delivery Time & 0.7682 & 0.2316 & 0.2303 & 0.4015 & 0.2745 & 0.0667 \\
\hline Packing & 0.4657 & 0.2571 & 0.2605 & 0.7113 & 0.2696 & 0.0706 \\
\hline Service after Buy & 0.5456 & 0.4883 & 0.2249 & 0.5217 & 0.2406 & 0.0832 \\
\hline
\end{tabular}

Figures depict the rotated factor loadings of service characteristics in a principal component analysis with orthogonal varimax rotation. Factor loadings above 0.5 are printed in bold. Uniqueness is the proportion of variance of the variable (e.g. Navigation) that is not accounted for by these five factors

to the "Kaiser-Criterion", the optimal number of factors should be determined by the number of eigenvalues higher than one. For our data, the "Kaiser-Criterion" would retain only one factor. In addition the "Scree Test", searching for a sharp change in the first differences of the eigenvalues, indicates that only one factor should be used. This is obviously not viable. A third approach-preserving as much information as possible in the potential factors - is to extend the number of factors until 90 or 95 percent of the variance can be explained. This would lead to four to seven factors. Given the spread of potential factor numbers, we have opted for the interpretability criterion (see Hatcher 1994): All solutions between the extreme values of the other selection criteria should be calculated and the most interpretable solution selected. In our case, five factors emerge as the optimal ones.

Table 3 shows the rotated factor loadings of the different service characteristics, based on a principal component analysis with orthogonal varimax rotation for five distinct factors. Factor loadings below 0.4 are usually considered as low and contribute little to the principal factor (in the table, factor loadings above 0.5 are printed in bold). The last column "Uniqueness" is the proportion of variance of the variable (e.g. Navigation) that is not accounted for by all of the factors used. Note that in 9 out of 14 cases, our chosen principal factors explain a communality (calculated as one minus uniqueness) of more than 90 percent of the original variance in the service characteristics. For the remaining five variables (Navigation, Product Info, Service before Buy, Website Performance, and Order Transaction), at least $85 \%$ of the original variance is explained. 
The following reduced set of factors can be calculated as linear predictions of the rotated factor loadings: The first factor Order comprises all the relevant aspects of the ordering process. Besides the choice options in form of the retailers' assortment, ${ }^{22}$ aspects such as the convenience of the ordering process, order confirmation and package tracking as well as the delivery time influence this unobserved factor. Examining the factor loadings, it emerges that the delivery times, in particular, as well as the individual's information needs (accuracy of information and feedback on the order and shipment process), are the driving forces behind this factor. Legal conditions such as the terms of business and the terms of payment (e.g. payment options) load up to the second factor Terms \& Conditions. The functional aspects of the retailer's website, such as convenience of navigation, the speed and response rate of the web-server, and the provided product information are highly correlated with the third factor Web Performance. Post-delivery Service, covering all aspects of the ordering process after arrival at the delivery address is also an important area; the quality of packing and service after purchase (e.g. handling of warranty claims) contribute to this factor with factor loadings of above 0.5. Finally, the Shipping factor channels the consumers' satisfaction with shipping cost. As shipping costs also relate to payment conditions it is not surprising that the variable payment conditions have the second highest factor loading for this factor.

These factors can be compared to the service dimensions found by Parasuraman et al. (2005), who developed a 22-item scale with four dimensions: efficiency, fulfillment, system availability, and privacy. While their scales are based on focus group discussions, our scales are pre-defined by www.geizhals.at and cannot be manipulated. Still, there is strong correlation between these dimensions and ours; only privacy issues are absent in the items www.geizhals.at offers on the customer evaluation form. Bauer et al. (2006) identify five service qualities in online shopping: functionality and design, enjoyment, process, reliability, and responsiveness. Again, there are considerable analogies with our dimensions; only enjoyment and responsiveness are not explicitly present in the www.geizhals.at catalogue.

\subsection{Impact of service characteristics on online demand}

Table 4 contains the results of our negative binomial regressions. We show the marginal effects of the relative price and some other control variables, and two ways to measure service quality for an online shop; whereas the first two columns include the overall measure of the retailers' quality calculated by the average across all the different service characteristics, the remaining four columns use the more detailed principal factors from our factor analysis. In columns (1) and (3), the number of referral requests from the www.geizhals.at site to the retailer's shop (all clicks) is used as a dependent count variable. Columns (2) and (4) show the results for the

\footnotetext{
22 We now demonstrate the positive influence of this principal factor Order on the demand for the product offers of an online shop. Although a larger assortment is generally found to increase store patronage in brick-and-mortar stores (Briesch et al. 2008), studies on internet grocery stores also found a significant negative relationship between assortment size and category sales (Boatwright and Nunes 2001).
} 


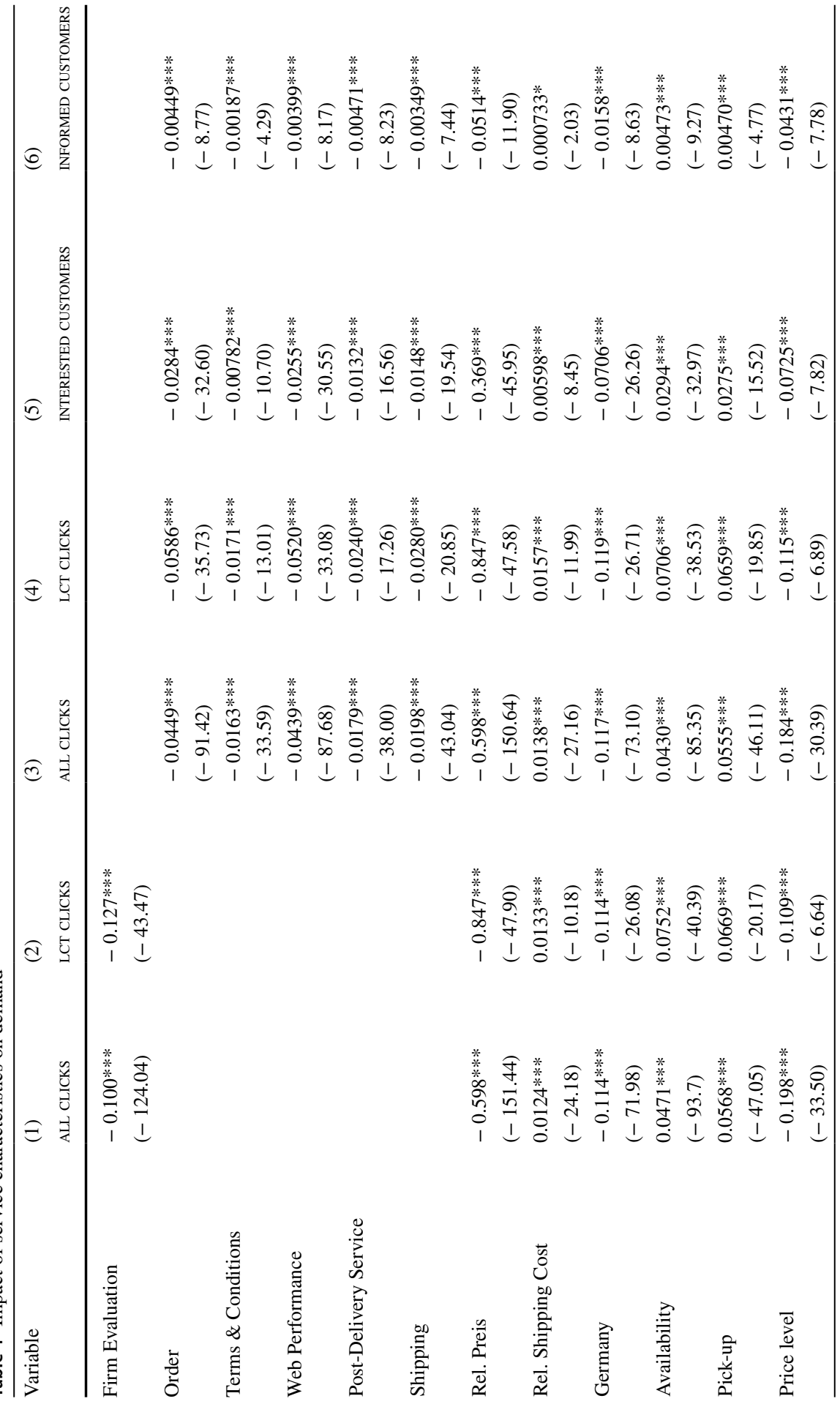




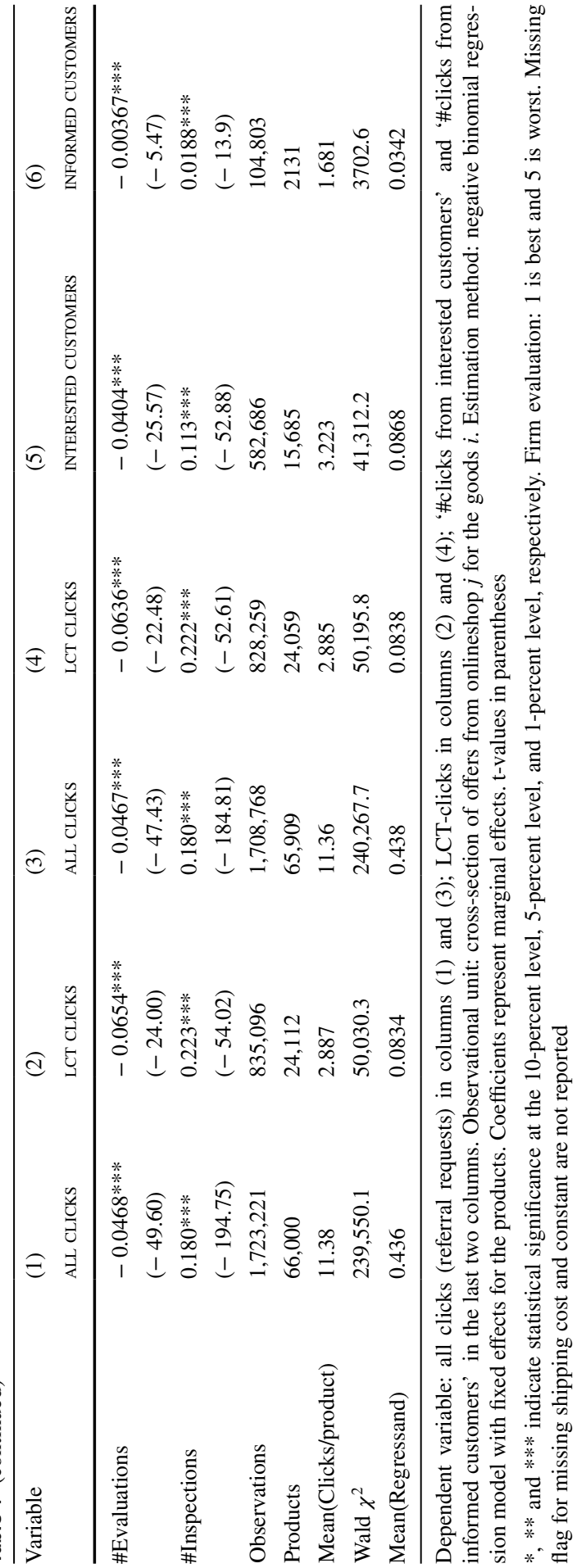


LCT count. Owing to the large number of observations, all the variables are significantly estimated and all have the expected sign, although we see some variation in the significance levels.

\subsubsection{Impact on referral requests}

In columns (1) and (3) we use clicks as dependent variable to measure the attention of customers for online-shops. Obviously, perceived service quality is an important determinant of attention in column (1). A decline in service quality by one grade in the 1-5 scale generates a log-difference in clicks by 0.100 , which represents $9.5 \%$ of the average amount of referral requests. Note that firm evaluations vary only with a relatively low standard deviation of 0.36 around the mean of 1.79 . Nevertheless, we measure a substantial and significant effect of change in consumers' firm valuations; Thompson and Haynes (2017) show that the possession of one additional star in reputation reduces the discount in price relative to the manufacturer's recommended selling price by only $1 \%$. It seems that quantity reacts stronger than prices on changes in service quality-this may be due to the strong visibility of prices in the explicit price ranking on www.geizhals.at.

Instead of the overall measure for service quality, Firm Evaluation, column (3) uses the more disaggregated principal factors. All factors influence the customers' attention in a highly significant and expected manner. Better service quality increases demand. However, the factors can be classified in two groups of very important and less important service characteristics. ${ }^{23}$ It turns out that the factor Order (summarizing the customers' valuation of the convenience with the ordering process within the website) together with the factor Website Performance (showing the customers satisfaction with the navigation process, the quality of product infos, as well as the reaction rate of the shop software) are decisive features influencing the customers' attention. The other factors Terms \& Conditions, Post-Delivery Service, as well as Shipping play only a minor role.

\subsubsection{Control variables}

Inspecting our other control variables, it is not surprising that the relative price of an offer is a very important variable ${ }^{24}$; an increase in the relative price by $10 \%$ would decrease the log difference of clicks by -0.0598 clicks. Given the mean of 0.44 clicks per firms' product offers, this results in a 5.8\% reduction in demand. Other firm-specific characteristics corroborate theoretical predictions and also have a substantial impact on demand; shops located in Germany attract $10.8 \%$ less demand from Austrian customers. Presumably, customers fear warranty or delivery problems across borders. Immediately available product offers have $4.8 \%$ higher referral

\footnotetext{
23 As we have standardized our factors to a mean of 0 and a standard deviation of 1 , we can directly compare the size of the coefficients.

${ }^{24}$ Empirical statements on the comparative statistics refer to column (1).
} 
requests. Offers with an additional pick-up possibility-the online shop is part of a brick-and-mortar store-receive 5.8\% more clicks.

A comparison with older Austrian data in Dulleck et al. (2011) shows decreasing importance of customer valuations and increasing impact of relative price over time. It seems that customers' confidence in e-commerce transactions increases over time, which makes price differences between shops relatively more important. With a similar argument, we can explain the decline of discrimination toward German shops. However, the service feature "pick up possibility" becomes more important over the years.

At first glance, the fact that relative shipping cost has a slight positive effect on demand is surprising; doubling the shipping cost increases referral requests by 1.2 percent. This result may be explained with the successful working of obfuscation strategies in online markets; attract customers with low product prices and generate profits with high shipping costs or more expensive complements. ${ }^{25}$ Hamilton and Srivastava (2008) analyze price partitioning on the internet with examples of price and shipping cost. It seems that customers only start looking at shipping cost once they become interested in buying from the shop. The shipping cost amount is the only variable that we have to parse from a text field. Therefore, some $10 \%$ of the cases cannot be properly coded. These missing cases are included with the mean shipping cost and are accounted for with a missing flag variable. As expected, the firm-specific general price level, representing the average relative price of all other goods offered by the respective retailer, has a negative effect on attention; an increase in the price level of the other offered goods by $10 \%$ reduces attention by $2 \%$. Hence, retailers with a reputation for relatively low prices attract more consumers, a result that is quite remarkable in highly transparent online markets.

The higher the number of inspections of detailed customer evaluations, the higher is the number of clicks. Apparently, \#Inspections acts as an indicator of the attractiveness of an online shop. However, as a high number of quality evaluations is a prerequisite for inspection by customers, ${ }^{26}$ the coefficients of \#Inspections and \#Evaluations have to be interpreted jointly. If the \#Evaluations enters our estimation without the \#Inspections, we observe a robust positive and highly significant coefficients for the number of evaluations, as expected (results not shown in the tables). Obviously, an increasing number of firm evaluations has a positive effect on demand, because customers might trust the reliability of the shop and the evaluations further. Although the inclusion of \#Inspections changes the sign of \#Evaluations, we should not oversee the positive aggregate effect-as the negative coefficient of \#Evaluations is relatively small, the total effect of a higher number of evaluations on the number of clicks is unambiguously positive considering the relatively strong and positive correlation between \#Inspections and \#Evaluations. For all our explanatory

\footnotetext{
25 We gauge a negative - albeit low-correlation of -0.05 between the relative price and the relative shipping cost. This low figure is not surprising if one considers that the shipping cost typically represents only a fraction of the product price; hence the possibilities for shipping-cost-based obfuscation strategies are limited.

26 We observe a relatively high correlation of 0.41 between \#Evaluations and \#Inspections.
} 
variables, the results concerning our control variables are robust across all estimations with different dependent variables.

\subsubsection{Impact on Last-Click-Through clicks: a proxy for actual purchases}

Thus far we have discussed the influence of service characteristics on referral requests. Unfortunately, the actual act of purchasing a product is unknown, because actual purchases occur at the e-tailer's own website, which cannot be observed by www.geizhals.at, and therefore, by us. We use the Last-click-Through concept as a proxy for actual purchases. Columns (2) and (4) show the results for our fixedeffects negative-binomial regressions.

The results from LCT regressions behave as expected. Theoretically, all the reliability and quality aspects of the e-tailer should become more important in an actual purchasing decision. This is exactly what we observe-with a falling mean of the dependent variable, practically all coefficients increase. ${ }^{27}$ To mention one example, for our LCT measure, a deterioration of the customer valuation by one grade would reduce the amount of LCTs by $-11.9 \%$ (compared with $-9.5 \%$ for referral requests).

The use of LCTs as dependent variables also increases the importance of our service characteristics in column (4). The service characteristics Order and Web Presence remain the decisive factors. Although we see that Shipping, and to a lesser degree, the Post-Delivery Service gain relatively in importance compared to the main indicator Order, the remaining factors Terms \& Conditions, and especially, Website Performance, lose in relative importance. These results are consistent with the expectation that factors are more relevant if it comes to actual purchases.

In addition, our other controls behave as expected, the relative price and the availability of the product offer become more important if we reduce our analysis to referral clicks with a higher purchase probability. The homeward bias of Austrian consumers remains relatively constant. As expected, shops with a reputation for low prices lose some of their advantage if it comes to actual purchases.

\subsubsection{Interested and informed customers}

Estimates in columns (1) and (3) of Table 4 use the clicks of all consumers as dependent variable, irrespective of whether the customers have informed themselves with detailed customer evaluations. ${ }^{28}$ Hence, the last two columns of Table 4 use an alternative approach; Column (5) only uses clicks from customers who have at least once inspected the detailed firm valuation of the different service characteristics for any firm in our sample (call them Interested Customers). Column (6) goes one step

\footnotetext{
27 On average, we have only 0.0834 LCTs per offer, which means that only 1 in $5(19.1 \%)$ clicks is an LCT. The actual conversion rates of online shops differ substantially between very low values of $0.5 \%$ for a Bike store and $30 \%$ for an online foodstuff store. This information is from personal communications of the authors with managers of online stores. Our measured "conversion rate" of $19.1 \%$ does not seem to be very far off.

28 Note that an additional click on the homepage is necessary to see the detailed firm evaluations for the different service quality variables.
} 
further and only counts clicks from customers who inspected the detailed customer valuations from the offering firm at least once (we call them Informed Customers). ${ }^{29}$ The negative binomial regressions for Interested Customers and Informed Customers show statistically robust and expected results. Although the last two columns show smaller coefficients, they refer to substantially lower means of the dependent variables. ${ }^{30}$ Interestingly, for those subgroups of consumers, the quantitative impact of service characteristics lessen somewhat. Whereas a deterioration of the factor Order by 1 would reduce the amount of all clicks by $-4.4 \%$, the values for columns (5) and (6) are $-2.8 \%$ and $-0.4 \%$, respectively. The dramatic reduction in sample size and the resulting sample selection to certain offers as well as the imbalance of information could be an explanation for this result. As these customers have only inspected certain shops, it does not necessarily mean that they are better informed. As we do not observe clicks from informed and interested customers for all of our products and firms, we lose different numbers of observations in the last two columns, whereby a direct comparison of the effects for informed and interested customers does not make sense. ${ }^{31}$

\subsection{Importance of service in different markets}

Online shops specialize in a certain branch of products (e.g. web shops specializing in the video and photo business) as well as general stores with a very broad assortment of products. Table 5 repeats our analysis separately for specific product categories: "Audio/Hifi", "Games", "Hardware", "Household articles", "Software", and "Video/Photo/TV." Table 5 and the following uses the clicks of all consumers as the dependent variable. The results for the aggregated firm evaluations are shown in Panel A in each table, and the marginal effects of disaggregated principal factors are included in Panel B.

Product Categories: Examining the results in Table 5, we see that the broad lines of our argument have been confirmed. On an aggregate level, firm evaluation is important for all markets, with the highest impact recorded for Audio and Hifi products. ${ }^{32}$ If we consider the different service characteristics in Panel B in detail, by and large, Order and Web Performance are again the most important service

\footnotetext{
29 As mentioned, customers can be identified by their pseudonymous IP-address. For each pseudonymous IP-address, we know whether the detailed customers' valuations have been inspected. For both variables, we take the sample of customers from columns (1) and (3) and check whether the conditions for the variable definition of Interested and Informed Customers hold.

${ }^{30}$ The mean of All Clicks amounts to 0.44, the values for Interested and Informed Customers are 0.087 and 0.034 , respectively. The lower means are not surprising, as the two additional variables are subsets from the previous ones.

31 If we perform our negative binomial regressions for the LCT of "interested customers," we get the expected result; for all service characteristics, we systematically observe higher coefficients. A corresponding estimation for "informed customers" is not possible. As only a small fraction of clicks are identified as LCTs and only a fraction of customers have at least once inspected the detailed firm valuation, we have not enough "informed customers" for whom we can calculate LCTs.

32 The different effects of our principal factors are again evaluated by the click difference in percent caused by a deterioration of the respective service quality factor by one.
} 
Table 5 Impact of service characteristics on referral requests of various product categories

\begin{tabular}{|c|c|c|c|c|c|c|}
\hline Category & $\begin{array}{l}\text { (1) } \\
\text { Audio/Hifi }\end{array}$ & $\begin{array}{l}\text { (2) } \\
\text { Games }\end{array}$ & $\begin{array}{l}(3) \\
\text { Hardware }\end{array}$ & $\begin{array}{l}\text { (4) } \\
\text { Household }\end{array}$ & $\begin{array}{l}\text { (5) } \\
\text { Software }\end{array}$ & $\begin{array}{l}(6) \\
\text { Video/TV/ } \\
\text { Photo }\end{array}$ \\
\hline \multicolumn{7}{|c|}{ Panel A: Aggregated firm evaluations } \\
\hline $\begin{array}{l}\text { Firm Evalua- } \\
\text { tion }\end{array}$ & $\begin{array}{l}-0.266^{* * *} \\
(0.00843)\end{array}$ & $\begin{array}{l}-0.128 * * * \\
(0.00776)\end{array}$ & $\begin{array}{l}-0.0917 * * * \\
(0.000859)\end{array}$ & $\begin{array}{l}-0.0876^{* * *} \\
(0.00382)\end{array}$ & $\begin{array}{l}-0.0623 * * * \\
(0.00403)\end{array}$ & $\begin{array}{l}-0.104 * * * \\
(0.00230)\end{array}$ \\
\hline Rel. Price & $\begin{array}{l}-1.179 * * * \\
(0.0340)\end{array}$ & $\begin{array}{l}-0.722^{* * *} \\
(0.0315)\end{array}$ & $\begin{array}{l}-0.437 * * * \\
(0.00388)\end{array}$ & $\begin{array}{l}-1.063 * * * \\
(0.0200)\end{array}$ & $\begin{array}{l}-0.704 * * * \\
(0.0330)\end{array}$ & $\begin{array}{l}-0.899 * * * \\
(0.0130)\end{array}$ \\
\hline Other controls & Yes & Yes & Yes & Yes & Yes & Yes \\
\hline \multicolumn{7}{|c|}{ Panel B: Disaggregated firm evaluations } \\
\hline Order & $\begin{array}{l}-0.146^{* * *} \\
(0.00543)\end{array}$ & $\begin{array}{l}-0.0458 * * * \\
(0.00464)\end{array}$ & $\begin{array}{l}-0.0378 * * * \\
(0.000523)\end{array}$ & $\begin{array}{l}-0.0494 * * * \\
(0.00249)\end{array}$ & $\begin{array}{l}-0.0356 * * * \\
(0.00286)\end{array}$ & $\begin{array}{l}-0.0549 * * * \\
(0.00144)\end{array}$ \\
\hline $\begin{array}{l}\text { Terms \& Con- } \\
\text { ditions }\end{array}$ & $\begin{array}{l}-0.0365^{* * *} \\
(0.00498)\end{array}$ & $\begin{array}{l}-0.0249 * * * \\
(0.00502)\end{array}$ & $\begin{array}{l}-0.0161 * * * \\
(0.000494)\end{array}$ & $\begin{array}{l}-0.00503 \\
(0.00319)\end{array}$ & $\begin{array}{l}-0.00852 * * * \\
(0.00222)\end{array}$ & $\begin{array}{l}-0.0194 \text { *** } \\
(0.00151)\end{array}$ \\
\hline $\begin{array}{l}\text { Web Perfor- } \\
\text { mance }\end{array}$ & $\begin{array}{l}-0.0846^{* * *} \\
(0.00420)\end{array}$ & $\begin{array}{l}-0.0657 * * * \\
(0.00496)\end{array}$ & $\begin{array}{l}-0.0370 * * * \\
(0.000527)\end{array}$ & $\begin{array}{l}-0.0703^{* * *} \\
(0.00260)\end{array}$ & $\begin{array}{l}-0.0135^{* * *} \\
(0.00218)\end{array}$ & $\begin{array}{l}-0.04433^{* * *} \\
(0.00142)\end{array}$ \\
\hline $\begin{array}{l}\text { Post-Delivery } \\
\text { Service }\end{array}$ & $\begin{array}{l}-0.0410 \text { *** } \\
(0.00531)\end{array}$ & $\begin{array}{l}-0.0306^{* * *} \\
(0.00571)\end{array}$ & $\begin{array}{l}-0.0191 * * * \\
(0.000483)\end{array}$ & $\begin{array}{l}-0.0251^{* * *} \\
(0.00261)\end{array}$ & $\begin{array}{l}-0.00856^{* * *} \\
(0.00210)\end{array}$ & $\begin{array}{l}-0.0226^{* * *} \\
(0.00145)\end{array}$ \\
\hline Shipping & $\begin{array}{l}-0.0456^{* * *} \\
(0.00464)\end{array}$ & $\begin{array}{l}-0.0130 * * \\
(0.00462)\end{array}$ & $\begin{array}{l}-0.0205^{* * *} \\
(0.000480)\end{array}$ & $\begin{array}{l}-0.000557 \\
(0.00254)\end{array}$ & $\begin{array}{l}-0.0207^{* * *} \\
(0.00246)\end{array}$ & $\begin{array}{l}-0.0115^{\text {**** }} \\
(0.00135)\end{array}$ \\
\hline Rel. Price & $\begin{array}{l}-1.185^{* * *} \\
(0.0346)\end{array}$ & $\begin{array}{l}-0.716^{* * *} \\
(0.0318)\end{array}$ & $\begin{array}{l}-0.441 * * * \\
(0.00392)\end{array}$ & $\begin{array}{l}-1.045^{* * *} \\
(0.0200)\end{array}$ & $\begin{array}{l}-0.698^{\text {*** }} \\
(0.0331)\end{array}$ & $\begin{array}{l}-0.900^{* * * *} \\
(0.0131)\end{array}$ \\
\hline $\begin{array}{l}\text { Rel. Shipping } \\
\text { Cost }\end{array}$ & $\begin{array}{l}0.00455 \\
(0.00640)\end{array}$ & $\begin{array}{l}0.0341 * * \\
(0.0117)\end{array}$ & $\begin{array}{l}0.0170^{* * *} \\
(0.000886)\end{array}$ & $\begin{array}{l}0.0131 * * * \\
(0.00145)\end{array}$ & $\begin{array}{l}0.00925 \\
(0.00619)\end{array}$ & $\begin{array}{l}0.000217 \\
(0.00143)\end{array}$ \\
\hline Germany & $\begin{array}{l}-0.228 * * * \\
(0.0113)\end{array}$ & $\begin{array}{l}-0.262^{* * *} \\
(0.0154)\end{array}$ & $\begin{array}{l}-0.0812 * * * \\
(0.00179)\end{array}$ & $\begin{array}{l}-0.242 * * * \\
(0.00724)\end{array}$ & $\begin{array}{l}-0.0636^{* * * *} \\
(0.00853)\end{array}$ & $\begin{array}{l}-0.157 * * * \\
(0.00430)\end{array}$ \\
\hline Availability & $\begin{array}{l}0.0998 * * * \\
(0.00417)\end{array}$ & $\begin{array}{l}0.0721 * * * \\
(0.00496)\end{array}$ & $\begin{array}{l}0.0339 * * * \\
(0.000542)\end{array}$ & $\begin{array}{l}0.0540 * * * \\
(0.00221)\end{array}$ & $\begin{array}{l}0.0343 * * * \\
(0.00308)\end{array}$ & $\begin{array}{l}0.0709 * * * \\
(0.00144)\end{array}$ \\
\hline Pick-up & $\begin{array}{l}0.0840 \text { *** } \\
(0.0101)\end{array}$ & $\begin{array}{l}0.00272 \\
(0.0125)\end{array}$ & $\begin{array}{l}0.0706 * * * \\
(0.00140)\end{array}$ & $\begin{array}{l}0.0234 * * * \\
(0.00498)\end{array}$ & $\begin{array}{l}0.0252 * * * \\
(0.00642)\end{array}$ & $\begin{array}{l}0.0193 * * * \\
(0.00309)\end{array}$ \\
\hline Price level & $\begin{array}{l}0.212^{* * * *} \\
(0.0591)\end{array}$ & $\begin{array}{l}0.143 * * \\
(0.0532)\end{array}$ & $\begin{array}{l}-0.225^{* * *} \\
(0.00634)\end{array}$ & $\begin{array}{l}-0.549 * * * \\
(0.0339)\end{array}$ & $\begin{array}{l}-0.318^{* * *} \\
(0.0352)\end{array}$ & $\begin{array}{l}0.00362 \\
(0.0174)\end{array}$ \\
\hline \#Evaluations & $\begin{array}{l}-0.0834 * * * \\
(0.00788)\end{array}$ & $\begin{array}{l}-0.133^{* * *} \\
(0.0111)\end{array}$ & $\begin{array}{l}-0.0346^{* * *} \\
(0.00108)\end{array}$ & $\begin{array}{l}-0.0917 * * * \\
(0.00469)\end{array}$ & $\begin{array}{l}-0.0411^{* * *} \\
(0.00592)\end{array}$ & $\begin{array}{l}-0.0634 * * * \\
(0.00276)\end{array}$ \\
\hline \#Inspections & $\begin{array}{l}0.298 * * * \\
(0.00794)\end{array}$ & $\begin{array}{l}0.260 * * * \\
(0.00952)\end{array}$ & $\begin{array}{l}0.164 * * * \\
(0.00112)\end{array}$ & $\begin{array}{l}0.221 * * * \\
(0.00416)\end{array}$ & $\begin{array}{l}0.109 * * * \\
(0.00524)\end{array}$ & $\begin{array}{l}0.190 * * * \\
(0.00258)\end{array}$ \\
\hline Observations & 64,361 & 36,759 & $1,167,028$ & 158,621 & 39,584 & 237,900 \\
\hline $\begin{array}{r}\text { Number of } \\
\text { Products }\end{array}$ & 5368 & 2155 & 32,919 & 12,983 & 1428 & 10,286 \\
\hline $\begin{array}{c}\text { Mean(Clicks/ } \\
\text { Product) }\end{array}$ & 6.884 & 12.57 & 13.10 & 6.156 & 6.648 & 15.74 \\
\hline Wald $\chi^{2}$ & $10,876.2$ & 5883.1 & $164,199.8$ & $22,267.2$ & 3678.4 & $44,646.0$ \\
\hline $\begin{array}{l}\text { Mean } \\
\quad \text { (Regressand) }\end{array}$ & 0.574 & 0.737 & 0.370 & 0.504 & 0.240 & 0.681 \\
\hline
\end{tabular}

Dependent variable: all clicks (= referral requests). Observational unit: cross-section of offers from onlineshop $j$ for the goods $i$. Estimation method: negative binomial regression model with fixed effects 
Table 5 (continued)

for the products. Panel A includes estimations for aggregated firm evaluations. Panel B shows the result for disaggregated firm evaluations according to the factor analysis. Coefficients represent marginal effects. Standard errors in parentheses

$*, * *$ and *** indicate statistical significance at the 10-percent level, 5-percent level, and 1-percent level, respectively. Firm Evaluation: 1 is best and 5 is worst. Missing flag for missing shipping cost and constant are not reported

characteristics for all product categories. Noticeable is the relatively strong effect of Order in the Audio/Hifi category. Shipping conditions are more important than Web Performance for only the "Software" category. The specificity of information products is also demonstrated by the relatively small economic effects for our factors in the category "Games". Our results also show that the category of household appliances are specific, as both Terms \& Conditions and Shipping are statistically not significant. Apparently, other variables are more important in the decision for a specific shop offer than these two factors. The fact that household products only entered the price search engine in the recent past might explain this result.

In terms of the other firm-specific variables, relative price has the highest impact on the demand for household and Audio/Hifi products. For the IT-related product categories of Hardware and Software, the country of origin plays a very subordinate role. Almost all variables come up with expected signs and comparable coefficients across the different product groups. We only obtain contradicting coefficients for the general price level of a firm, which may be easily possible, because being a cheap shop may have quite different demand effects for high- or low-quality goods. In our classification, a more expensive shop increases demand for Audio/Hifi and Games, but reduces it for Hardware, Household appliances, and Software.

Price of products: The first two columns in Table 6 stress another classificationthe price level of products. While column (1) shows the regression results for lowprice products, column (2) presents the results for products with price above the mean. Note that, on average, high-price products are clicked nearly three times as often-obviously, consumers inform themselves better on expensive products. We expect that a purchasing decision in the case of more expensive products is more thoughtful; hence, we would expect higher coefficients, especially for the relative price. Panel A confirms these expectations. Both the relative price and customer valuations become more important for expensive goods. The comparison of service factors in Panel B indicate an even greater shift toward the factors Web Performance and Order for high-price products.

Information versus non-information goods: columns (3) and (4) compare information goods (e.g. games and software products) and non-information goods (e.g. Audio/Hifi, Hardware, Video/Photo, TV, appliances). Overall these product groups are similar, although there exist some differences; consumers of information goods react stronger to Web Performance, while consumers of non-information goods give more relative importance to Shipping, a fact that might be related to the transport of bulkier goods.

Main products versus accessories: Table 7 juxtaposes the main products against accessories, that is products that are not used alone, but only in combination with a 


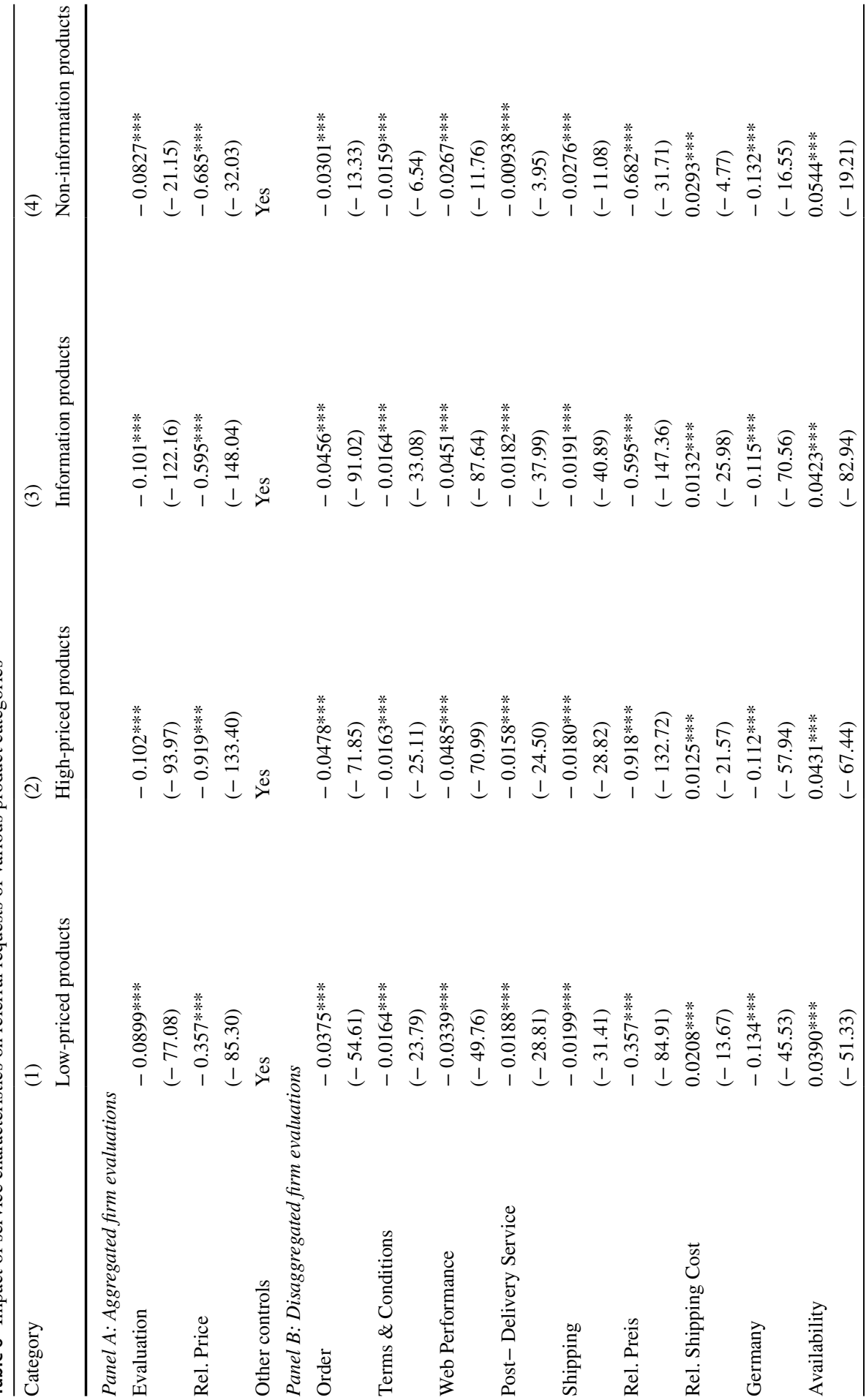




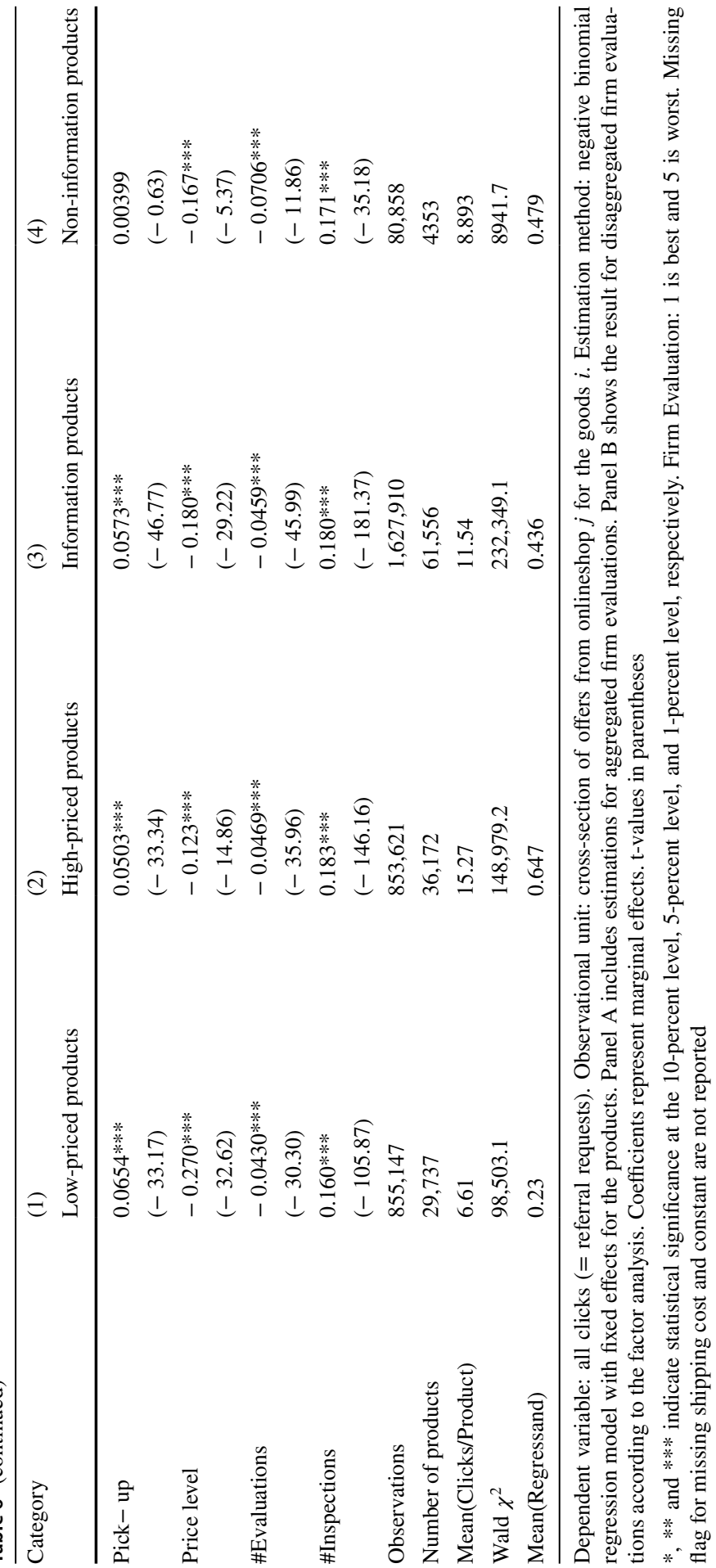


Table 7 Impact of service characteristics on referral requests of various product categories

\begin{tabular}{|c|c|c|c|c|}
\hline \multirow[t]{2}{*}{ Category } & (1) & (2) & (3) & (4) \\
\hline & Main products & High-priced accessory & Low-priced accessory & Other products \\
\hline \multicolumn{5}{|c|}{ Panel A: Aggregated firm evaluations } \\
\hline Firm Evaluation & $\begin{array}{l}-0.107 * * * \\
(-68.21)\end{array}$ & $\begin{array}{l}-0.106^{* * *} \\
(-36.42)\end{array}$ & $\begin{array}{l}-0.0919 \text { *** } \\
(-94.06)\end{array}$ & $\begin{array}{l}-0.0995^{* * * *} \\
(-8.78)\end{array}$ \\
\hline Rel. Price & $\begin{array}{l}-1.180 * * * \\
(-108.08)\end{array}$ & $\begin{array}{l}-0.835 * * * \\
(-47.96)\end{array}$ & $\begin{array}{l}-0.373 * * * \\
(-99.08)\end{array}$ & $\begin{array}{l}-0.999 * * * \\
(-12.16)\end{array}$ \\
\hline Other controls & Yes & Yes & Yes & Yes \\
\hline \multicolumn{5}{|c|}{ Panel B: Disaggregated firm evaluations } \\
\hline Order & $\begin{array}{l}-0.0509 \text { *** } \\
(-52.75)\end{array}$ & $\begin{array}{l}-0.0409 * * * \\
(-23.99)\end{array}$ & $\begin{array}{l}-0.0392^{* * *} \\
(-66.04)\end{array}$ & $\begin{array}{l}-0.0600 \text { *** } \\
(-8.68)\end{array}$ \\
\hline Terms \& Conditions & $\begin{array}{l}-0.0163^{* * *} \\
(-16.53)\end{array}$ & $\begin{array}{l}-0.0204 * * * \\
(-11.99)\end{array}$ & $\begin{array}{l}-0.0160 \text { *** } \\
(-28.06)\end{array}$ & $\begin{array}{l}-0.00822 \\
(-1.17)\end{array}$ \\
\hline Web Performance & $\begin{array}{l}-0.0532 * * * \\
(-53.08)\end{array}$ & $\begin{array}{l}-0.0505^{* * *} \\
(-28.49)\end{array}$ & $\begin{array}{l}-0.0356^{* * *} \\
(-60.88)\end{array}$ & $\begin{array}{l}-0.0584 * * * \\
(-7.93)\end{array}$ \\
\hline Post-Delivery Service & $\begin{array}{l}-0.0188^{* * *} \\
(-19.14)\end{array}$ & $\begin{array}{l}-0.0196^{* * *} \\
(-11.67)\end{array}$ & $\begin{array}{l}-0.0183^{* * *} \\
(-33.29)\end{array}$ & $\begin{array}{l}-0.0214^{* *} \\
(-3.13)\end{array}$ \\
\hline Shipping & $\begin{array}{l}-0.0181^{* * *} \\
(-19.51)\end{array}$ & $\begin{array}{l}-0.0205^{* * *} \\
(-12.78)\end{array}$ & $\begin{array}{l}-0.0201 * * * \\
(-36.77)\end{array}$ & $\begin{array}{l}-0.00893 \\
(-1.43)\end{array}$ \\
\hline Rel. Preis & $\begin{array}{l}-1.179 * * * \\
(-106.95)\end{array}$ & $\begin{array}{l}-0.841 * * * \\
(-47.62)\end{array}$ & $\begin{array}{l}-0.375^{* * *} \\
(-98.97)\end{array}$ & $\begin{array}{l}-0.990 * * * \\
(-12.00)\end{array}$ \\
\hline Rel. Shipping Cost & $\begin{array}{l}0.0117 * * * \\
(-16.37)\end{array}$ & $\begin{array}{l}-0.00781 * * \\
(-2.81)\end{array}$ & $\begin{array}{l}0.0189 * * * \\
(-15.68)\end{array}$ & $\begin{array}{l}-0.0165 \\
(-1.37)\end{array}$ \\
\hline Germany & $\begin{array}{l}-0.147^{* * *} \\
(-51.60)\end{array}$ & $\begin{array}{l}-0.0883^{* * *} \\
(-18.05)\end{array}$ & $\begin{array}{l}-0.103^{* * *} \\
(-47.25)\end{array}$ & $\begin{array}{l}-0.143^{* * *} \\
(-6.90)\end{array}$ \\
\hline Availability & $\begin{array}{l}0.0473 * * * \\
(-51.16)\end{array}$ & $\begin{array}{l}0.0393 * * * \\
(-24.86)\end{array}$ & $\begin{array}{l}0.0389 * * * \\
(-61.87)\end{array}$ & $\begin{array}{l}0.0707 * * * \\
(-9.63)\end{array}$ \\
\hline Pick-up & $\begin{array}{l}0.0347 * * * \\
(-17.01)\end{array}$ & $\begin{array}{l}0.0465 * * * \\
(-12.14)\end{array}$ & $\begin{array}{l}0.0689 * * * \\
(-42.11)\end{array}$ & $\begin{array}{l}0.0223 \\
(-1.53)\end{array}$ \\
\hline Price level & $\begin{array}{l}0.0382 * * \\
(-3.09)\end{array}$ & $\begin{array}{l}0.0206 \\
(-1)\end{array}$ & $\begin{array}{l}-0.314 * * * \\
(-43.09)\end{array}$ & $\begin{array}{l}-0.0478 \\
(-0.59)\end{array}$ \\
\hline \#Evaluations & $\begin{array}{l}-0.0590^{* * *} \\
(-32.51)\end{array}$ & $\begin{array}{l}-0.0507 * * * \\
(-14.70)\end{array}$ & $\begin{array}{l}-0.0372^{* * *} \\
(-29.67)\end{array}$ & $\begin{array}{l}-0.0405^{* * *} \\
(-3.45)\end{array}$ \\
\hline \#Inspections & $\begin{array}{l}0.203^{* * *} \\
(-112.59)\end{array}$ & $\begin{array}{l}0.176^{* * *} \\
(-51.07)\end{array}$ & $\begin{array}{l}0.162 * * * \\
(-130.78)\end{array}$ & $\begin{array}{l}0.162 * * * \\
(-12.68)\end{array}$ \\
\hline Observations & 466,008 & 126,336 & $1,080,785$ & 9368 \\
\hline Number of products & 23,783 & 4913 & 36,255 & 374 \\
\hline Mean(Clicks/Product) & 14.72 & 11.25 & 9.131 & 11.07 \\
\hline Wald $\chi^{2}$ & $94,557.8$ & $23,002.6$ & $125,843.4$ & 1992.7 \\
\hline Mean(Regressand) & 0.751 & 0.437 & 0.306 & 0.442 \\
\hline
\end{tabular}

Dependent variable: all clicks (= referral requests). Observational unit: cross-section of offers from onlineshop $j$ for the goods $i$. Estimation method: negative binomial regression model with fixed effects for the products. Panel A includes estimations for aggregated firm evaluations. Panel B shows the result for disaggregated firm evaluations according to the factor analysis. Coefficients represent marginal effects. $\mathrm{t}$-values in parentheses 
Table 7 (continued)

*, ** and *** indicate statistical significance at the 10-percent level, 5-percent level, and 1-percent level, respectively. Firm Evaluation: 1 is best and 5 is worst. Missing flag for missing shipping cost and constant are not reported

main product. We refer to the classification system of www.geizhals.at, which assigns all products into a hierarchical system of categories, subcategories, and subsubcategories. Products within the subsubcategories are typically substitutes. We have classified each subsubcategory into main products in column (1) (e.g. single-lens reflex cameras SLR), expensive accessories in column (2) (e.g. lenses for an SLR), and cheap accessories in column (3) (e.g. SD-cards for the SLR). The remaining subsubcategories, for which no classification was possible, are subsumed as "Others" in column (4). Most of the products can be found in main products and cheap accessories. Again, our expectation would be that consumers make well-considered decisions for main products and expensive accessories. For cheap accessories, the purchase decision is often made within the shop's website and not at the price search engine. Saving shipping cost is one motivation for this behavior. A glance at Panel A confirms our expectations. For main products and expensive accessories, we see higher coefficients for the general quality evaluation of firms than for other categories. As expected, the relative price of cheap accessories has the lowest effect on customer clicks. Unsurprisingly, we again observe the shift toward Order and Web Performance for main products and expensive accessories. The same is true for the category "Others".

Firm types: Table 8 compares the impact of service characteristics for different firm types. In columns (1) and (2) the median of the shops' total number of clicks on all offered products is used to distinguish large and small firms. In columns (3) and (4), the median of the total number of shops' evaluations separates firms into samples of few and many evaluations. By separating these groups, we can analyze the impact of different service characteristics for firms that are "widely known", compared to other small stores. We would expect stronger impacts of service characteristics for larger firms, which typically have more customer evaluations. The systematically higher coefficients of service characteristics for larger shops with more customer evaluations demonstrate that customer reviews may help overcome information asymmetries.

Sum up: We observe a recurring pattern that customers react positively to Order and Web Performance, especially for high-priced or main products. Online shops typically want to sell these products because they bring higher profits and sales (e.g. main products also sell complementary products). To attract customers for these products, our results demonstrate the importance of investments into the convenience of the ordering process, order confirmation, package tracking, and delivery time. Moreover, firms should invest in functional aspects of the retailer's website, such as convenience of navigation, the speed and response rate of the web-server, and the provided product information. We measure a systematically higher impact of service characteristics, especially in large firms with a high number of customer evaluations. 
Table 8 Impact of service characteristics on referral requests for different types of firms

\begin{tabular}{|c|c|c|c|c|}
\hline \multirow[t]{2}{*}{ Category } & (1) & (2) & (3) & (4) \\
\hline & Large firms & Small firms & Many evaluations & Few evaluations \\
\hline \multicolumn{5}{|c|}{ Panel A: Aggregated firm evaluations } \\
\hline Firm Evaluation & $\begin{array}{l}-0.114 * * * \\
(-115.78)\end{array}$ & $\begin{array}{l}-0.0311^{* * *} \\
(-10.26)\end{array}$ & $\begin{array}{l}-0.143 * * * \\
(-121.43)\end{array}$ & $\begin{array}{l}-0.0187^{* * *} \\
(-11.11)\end{array}$ \\
\hline Rel. Price & $\begin{array}{l}-0.691 * * * \\
(-147.44)\end{array}$ & $\begin{array}{l}-0.436^{* * *} \\
(-18.82)\end{array}$ & $\begin{array}{l}-0.753 * * * \\
(-143.22)\end{array}$ & $\begin{array}{l}-0.528 * * * \\
(-31.26)\end{array}$ \\
\hline Other controls & Yes & Yes & Yes & Yes \\
\hline \multicolumn{5}{|c|}{ Panel B: Disaggregated firm evaluations } \\
\hline Order & $\begin{array}{l}-0.0513^{* * *} \\
(-80.77)\end{array}$ & $\begin{array}{l}-0.0187^{* * *} \\
(-11.10)\end{array}$ & $\begin{array}{l}-0.0738 * * * \\
(-89.52)\end{array}$ & $\begin{array}{l}-0.00860^{* * *} \\
(-10.05)\end{array}$ \\
\hline Terms \& Conditions & $\begin{array}{l}-0.0234 * * * \\
(-37.59)\end{array}$ & $\begin{array}{l}0.0187 * * * \\
(8.50)\end{array}$ & $\begin{array}{l}-0.0120 * * * \\
(-9.82)\end{array}$ & $\begin{array}{l}0.000715 \\
(0.87)\end{array}$ \\
\hline Web Performance & $\begin{array}{l}-0.0499 * * * \\
(-75.14)\end{array}$ & $\begin{array}{l}-0.0145^{* * *} \\
(-10.29)\end{array}$ & $\begin{array}{l}-0.0711 * * * \\
(-85.52)\end{array}$ & $\begin{array}{l}-0.0107 * * * \\
(-12.21)\end{array}$ \\
\hline Post-Delivery Service & $\begin{array}{l}-0.0263^{* * *} \\
(-41.97)\end{array}$ & $\begin{array}{l}-0.00544^{* * *} \\
(-3.62)\end{array}$ & $\begin{array}{l}-0.0376^{* * *} \\
(-46.69)\end{array}$ & $\begin{array}{l}0.00260 * * \\
(2.81)\end{array}$ \\
\hline Shipping & $\begin{array}{l}-0.0185^{* * *} \\
(-30.57)\end{array}$ & $\begin{array}{l}-0.0172 * * * \\
(-9.69)\end{array}$ & $\begin{array}{l}-0.0201 * * * \\
(-23.84)\end{array}$ & $\begin{array}{l}-0.00338^{* * *} \\
(-3.63)\end{array}$ \\
\hline Rel. Preis & $\begin{array}{l}-0.700 * * * \\
(-146.84)\end{array}$ & $\begin{array}{l}-0.416^{* * *} \\
(-18.67)\end{array}$ & $\begin{array}{l}-0.766^{* * *} \\
(-143.17)\end{array}$ & $\begin{array}{l}-0.508 * * * \\
(-29.62)\end{array}$ \\
\hline Rel. Shipping Cost & $\begin{array}{l}0.0144 * * * \\
(23.36)\end{array}$ & $\begin{array}{l}0.00409 \\
(0.78)\end{array}$ & $\begin{array}{l}0.0168 * * * \\
(23.80)\end{array}$ & $\begin{array}{l}0.0133^{* * * *} \\
(4.40)\end{array}$ \\
\hline Germany & $\begin{array}{l}-0.133 * * * \\
(-70.00)\end{array}$ & $\begin{array}{l}-0.117 * * * \\
(-12.55)\end{array}$ & $\begin{array}{l}-0.131 * * * \\
(-60.54)\end{array}$ & $\begin{array}{l}-0.191 * * * \\
(-26.22)\end{array}$ \\
\hline Availability & $\begin{array}{l}0.0560^{* * * *} \\
(90.36)\end{array}$ & $\begin{array}{l}0.0266^{* * * *} \\
(9.74)\end{array}$ & $\begin{array}{l}0.0576^{* * *} \\
(83.12)\end{array}$ & $\begin{array}{l}0.0233^{* * * *} \\
(13.84)\end{array}$ \\
\hline Pick-up & $\begin{array}{l}0.0569 * * * \\
(40.78)\end{array}$ & $\begin{array}{l}0.0559 * * * \\
(5.86)\end{array}$ & $\begin{array}{l}0.0717 * * * \\
(43.40)\end{array}$ & $\begin{array}{l}0.0603 * * * \\
(12.12)\end{array}$ \\
\hline Price level & $\begin{array}{l}-0.231 * * * \\
(-30.23)\end{array}$ & $\begin{array}{l}-0.152^{* * *} \\
(-7.12)\end{array}$ & $\begin{array}{l}-0.120^{* * *} \\
(-13.45)\end{array}$ & $\begin{array}{l}-0.338^{* * *} \\
(-19.16)\end{array}$ \\
\hline \#Evaluations & $\begin{array}{l}-0.0636 * * * \\
(-52.59)\end{array}$ & $\begin{array}{l}0.869 * * * \\
(7.57)\end{array}$ & $\begin{array}{l}-0.0706^{* * *} \\
(-49.67)\end{array}$ & $\begin{array}{l}3.319 * * \\
(2.94)\end{array}$ \\
\hline \#Inspections & $\begin{array}{l}0.208 * * * \\
(177.01)\end{array}$ & $\begin{array}{l}-0.214 * * * \\
(-7.32)\end{array}$ & $\begin{array}{l}0.235^{* * * *} \\
(172.99)\end{array}$ & $\begin{array}{l}0.177 * * * \\
(23.47)\end{array}$ \\
\hline Observations & 466,008 & 126,336 & $1,080,785$ & 9368 \\
\hline Number of products & 23,783 & 4913 & 36,255 & 374 \\
\hline Mean(Clicks/Product) & 14.72 & 11.25 & 9.131 & 11.07 \\
\hline Wald $\chi^{2}$ & $94,557.8$ & $23,002.6$ & $125,843.4$ & 1992.7 \\
\hline Mean(Regressand) & 0.751 & 0.437 & 0.306 & 0.442 \\
\hline
\end{tabular}

Dependent variable: all clicks (= referral requests). The median of the shops' total number of clicks on all offered products is used to distinguish in large and small firms. The median of the total number of shops' evaluations separates firms into the samples of few and many evaluations. Observational unit: cross-section of offers from onlineshop $j$ for the goods $i$. Estimation method: negative binomial regression model with fixed effects for the products. Panel A includes estimations for aggregated firm evalua- 
Table 8 (continued)

tions. Panel B shows the result for disaggregated firm evaluations according to the factor analysis. Coefficients represent marginal effects. t-values in parentheses

$*, * *$ and ***indicate statistical significance at the 10-percent level, 5-percent level, and 1-percent level, respectively. Firm Evaluation: 1 is best and 5 is worst. Missing flag for missing shipping cost and constant are not reported

\section{Discussion and limitations}

Based on the factor analysis of customers' service evaluations and regression analyses of click data from the Austrian price search engine (www.geizhals.at), we have empirical evidence for the following managerial conclusions:

- The relative product price is the most important variable in e-business; however, customer evaluations of the service quality of online shops also have a high impact on attention. Our study complements research on the price effects of seller reputation (Thompson and Haynes 2017), which shows relatively small effects of reputation on prices achieved in such online markets. According to our estimates, quantities reactions (i.e. attention or LCTs) on service characteristics is substantial.

- We measure an even stronger impact of service characteristics on consumers attention in case of customers who actively inspect other customers' firm evaluations (informed and interested customers).

- In their marketing mix, online shops have to be aware that aspects of service quality influence the attention received by a specific online shop in price search engines on the one hand, and actual online sales on the other hand, in different ways.

- Aspects of service quality associated with the ordering process and the firms' website performance are the most important quality indicators. This is true everywhere, but especially in the "Audio/Hifi" category. In particular, satisfaction with the transaction of the ordering process, the validity of information, confirmations on the ordering and package tracking and the delivery time, determine the service quality of the ordering process. Website performance is characterized by the simplicity of navigation within the website, the amount of product information, and the response of the shops' webserver.

- Other service quality aspects such as Terms \& Conditions, Post-Delivery Service and Shipping conditions, play a minor role for attention in all product categories. Although these factors are less significant than the others, they could very well affect repeat sales.

- Service quality related to the ordering process and the firms' website performance become even more important for high-priced goods and the main products (instead of accessories). This result emphasizes the importance of order handling and website performance, as these products typically generate profits and sales.

- Pick-up possibility at the shop and the immediate availability of the product are important for clicks. Our results concerning the reputation of being a low-cost shop are ambiguous; only in the categories of Hardware, Household appliances, and Software, a lower general price level for the shop attracts additional potential 
consumers, whereas for Audio, Hifi, and Games it even reduces demand. These general signals of being a low- vs. high-cost shop have to be applied with care.

- Even if there are no language barriers and the market is an integrated one with no customs restraints, we can observe that foreign e-commerce shops are at a disadvantage. Online shops interested in cross-border shopping must invest in establishing trust and confidence in order to overcome this cross-border disadvantage.

- As potential customers can never be sure of the reliability of a shop's service quality information, as provided by fellow shoppers, they are much more relaxed if the number of such evaluations is high. This result assigns an important role to the intermediary, the shopbot: increasing the reliability of the evaluations by encouraging customer feedback and applying careful quality management to detect "gaming" is highly rewarding.

- Finally, we find that service characteristics have higher impact on customer attention in large shops, which have a high number of customer reviews.

As our study uses an existing recommendation system with given characteristics, it is not possible to assess the adequateness of these characteristics. Further research could experiment with different recommendation systems and attempt to link clicks data with actual purchases. Owing to the technical construction of Geizhals.at, such a link is currently not possible.

\section{Conclusions}

Differences in service and reliability of shops are important arguments in explaining attention to and demand for homogeneous products in e-commerce. Our study offers a systematic investigation of the impact of service quality in e-tailing based on data from a price search engine. As indicators for the variation in the shops' service quality, we use the customers' actually perceived service quality depicted in shop evaluations at the price search engines' website. Referral requests from a price search engine to shops' websites as well as Last-Click-Through clicks (indicating a higher probability that an actual purchase has happened) are used to measure customer reaction to service quality. As it can be assumed that attention closely correlates with actual shop purchases, we deliver important evidence for the success or failure of e-commerce firms' strategies. Our study extends the existing literature by considering how different dimensions of service quality influence actual clicking, and therefore, purchasing behavior, in online markets.

Our main results show that—next to the price-service characteristics are important determinants of customers' attention and click behavior in online markets. Most important are service quality aspects associated with the ordering process and the firms' web site performance (e.g. satisfaction with the transaction of the ordering process, the validity of information, confirmations on the ordering and package tracking as well as the delivery time). These factors are most important for expensive information goods and for large firms whose service characteristics are already well and often evaluated. A reduction of the uncertainty in the buying process improves the genuine advantage of large, well-established and reliable e-commerce firms. 
Acknowledgements Open access funding provided by Johannes Kepler University Linz. This research was supported by funds of the Oesterreichische National-bank (Anniversary Fund, Project Number: 16255). Thanks to Johann Bacher for his helpful comments, to seminar participants in Innsbruck, Berlin, and Munich, and at the Austrian Economic Association Meetings, and to www.geizhals.at for giving us access to the data and providing useful advice.

Open Access This article is distributed under the terms of the Creative Commons Attribution 4.0 International License (http://creativecommons.org/licenses/by/4.0/), which permits unrestricted use, distribution, and reproduction in any medium, provided you give appropriate credit to the original author(s) and the source, provide a link to the Creative Commons license, and indicate if changes were made.

\section{References}

Backhaus K, Erichson B, Plinke W (2008) Multivariate Ana-lysemethoden. Eine anwendungsorientierte Einführung. Springer, Berlin

Bai X (2004) Why pay more? Why charge less? Heinz School of Public Policy and Management, Carnegie Mellon University, Pittsburgh, Working Paper

Bart YY, Shankar V, Sultan F, Urban GL (2005) Are the drivers and role of online trust the same for all web sites and consumers? A large scale exploratory empirical study. J Mark Res 69:133-152

Basilevsky A (1994) Statistical factor analysis and related methods: theory and applications. Wiley, New York

Bauer HH, Falk T, Hammerschmidt M (2006) eTransQual: a transaction process-based approach for capturing service quality in online shopping. J Bus Res 59(7):866-875

Blake BF, Neuendorf KA, Valdiserri CM (2005) Tailoring new websites to appeal to those most likely to shop online. Technovation 25(10):1205-1214

Boatwright P, Nunes JC (2001) Reducing assortment: an attribute-based approach. J Mark 65(3):50-63

Briesch RA, Chintagunta PK, Fox EJ (2008) How does assortment affect grocery store choice? J Mark Res 45:2-49

Burdett K, Coles M (1997) Steady state price distributions in a noisy search equilibrium. J Econ Theory 72:1-32

Burdett K, Judd K (1983) Equilibrium price dispersion. Econometrica 51:955-969

Cabral L, Hortaçsu A (2010) The dynamics of seller reputation: evidence from eBay. J Ind Econ 18(1):54-78

Cai H, Jin GZ, Liu C, Zhou L (2014) Seller reputation: from word-of-mouth to centralized feedback. Int $\mathrm{J}$ Ind Organ 34:51-65

Carlson J, McAfee P (1983) Discrete equilibrium price dispersion. J Polit Econ 91(June):480-493

Clemons E, Hann I-H, Hill L (2002) Price dispersion and differentiation in online travel: an empirical investigation. Manag Sci 48(4):534-549

Constantinides E (2006) The marketing mix revisited: towards the 21st century marketing. J Mark Manag 22:407-438

Costello AB, Osborne JW (2005) Best practices in exploratory factor analysis: four recommendations for getting the most from your analysis. Pract Assess Res Eval 10(7):1-9

Dulleck U, Hackl F, Weiss B, Winter-Ebmer R (2011) Buying online: an analysis of shopbot visitors. German Econ Rev 12(4):395-408

Einav L, Farronato C, Levin J (2016) Peer-to-peer markets. Ann Rev Econ 8(1):615-635

Elfenbein DW, Fisman R, Mcmanus B (2012) Charity as a substitute for reputation: evidence from an online marketplace. Rev Econ Stud 79(4):1441-1468

Ellison G, Ellison SF (2009) Search, obfuscation, and price elasticities on the internet. Econometrica $77(2): 427-452$

Fan Y, Jiandong J, Xiao M (2016) Reputation premium and reputation management: evidence from the largest e-commerce platform in China. Int J Ind Organ 46:63-76

Fishman A (1992) Search technology, staggered price-setting, and price dispersion. Am Econ Rev $82: 287-298$ 
Gabszewicz J, Thisse J (1979) Price competition, quality and income disparities. J Econ Theory 20(3):340-359

Hackl F, Kummer ME, Winter-Ebmer R (2014a) 99 cent: price points in e-commerce. Inf Econ Policy 26:12-27

Hackl F, Kummer ME, Winter-Ebmer R, Zulehner C (2014b) Market structure and market performance in E-commerce. Eur Econ Rev 68:199-218

Hamilton RW, Srivastava J (2008) When $2+2$ is not the same as $1+3$ : variations in price sensitivity across components of partitioned prices. J Mark Res 45:450-461

Hatcher L (1994) A step-by-step approach to using the SAS system for factor analysis and structural equation modeling. SAS Institute Inc., Cary

Hauser JR, Wernerfelt B (1990) An evaluation cost model of consideration sets. J Consum Res 16(March):393-408

Hausman J, Hall BH, Griliches Z (1984) Econometric models for count data with an application to the patents-R \& D relationship. Econometrica 52(4):909-938

Homburg C, Hoyer WD, Fassnacht M (2002) Service orientation of a retailer's business strategy: dimensions, antecedents, and performance outcomes. J Mark Res 66:86-101

Kalyanam K, McIntyre S (2002) The E-marketing mix: a contribution of the E-tailing wars. J Acad Mark Sci 30(4):487-499

Klein TJ, Lambertz C, Stahl KO (2016) Market transparency, adverse selection, and Moral Hazard. J Polit Econ 124(6):1677-1713

Lancaster KJ (1966) A new approach to consumer theory. J Polit Econ 74(1):132-157

Mussa M, Rosen S (1978) Monopoly and product quality. J Econ Theory 18(2):301-317

Nisar TM, Prabhakar G (2017) What factors determine e-satisfaction and consumer spending in e-commerce retailing? J Retail Consum Serv 39:135-144

Oh J, Fiorito SS, Cho H, Hofacker CF (2008) Effects of design factors on store image and expectation of merchandise quality in web-based stores. J Retail Consum Serv 15(4):237-249

Oliveira T, Alhinho M, Rita P, Dhillon G (2017) Modelling and testing consumer trust dimensions in e-commerce. Comput Hum Behav 71:153-164

Pallant JI, Danaher PJ, Sands SJ, Danaher TS (2017) An empirical analysis of factors that influence retail website visit types. J Retail Consum Serv 39:62-70

Parasuraman A, Zeithaml VA, Malhotra A (2005) E-S-QUAL: a multiple-item scale for assessing electronic service quality. J Serv Res 7(3):213-233

Resnick P, Zeckhauser R, Swanson J, Lockwood K (2006) The value of reputation on eBay: a controlled experiment. Exp Econ 2:79-101

Rosen S (1974) Hedonic prices and implicit markets: product differentiation in pure competition. J Polit Econ 82(1):34-55

Salop S, Stiglitz J (1982) The theory of sales: a simple model of equilibrium price dispersion with identical agents. Am Econ Rev 72:1121-1130

Schlosser AE, White TB, Lloyd SM (2006) Converting web site visitors into buyers: how web site investment increases consumer trusting beliefs and online purchase intentions. J Mark Res 70:133-148

Smith MD, Brynjolfsson E (2001) Consumer decision-making at an internet shopbot: brand still matters. J Ind Econ 49(4):541-558

StataCorp (2013) Stata 13 base reference manual. Stata Press, College Station

Stigler G (1991) The economics of information. J Polit Econ 69(June):213-225

Thompson S, Haynes M (2017) The value of online seller reputation: evidence from a price comparison site. Manag Decis Econ 38:302-313

Wolfinbarger M, Gilly MC (2003) eTailQ: dimensionalizing, measuring and predicting etail quality. J Retail 79(3):183-198

Worm S, Bharadwaj SG, Ulaga W, Reinartz WJ (2017) When and why do customer solutions pay off in business markets? J Acad Mark Sci 45(4):490-512

Zeithaml V, Parasuraman A, Malhotra A (2002) Service quality delivery through web sites: a critical review of extant knowledge. J Acad Mark Sci 30(4):362-375

Publisher's Note Springer Nature remains neutral with regard to jurisdictional claims in published maps and institutional affiliations. 